\author{
UNIVERSITY OF SÃO PAULO \\ SÃO CARLOS SCHOOL OF ENGINEERING \\ MATERIALS ENGINEERING DEPARTMENT
}

ANA BEATRIZ VERDI EMILIO

Hindered densification as a porogenic mechanism for alumina-based thermal insulators

São Carlos 

ANA BEATRIZ VERDI EMILIO

\section{Hindered densification as a porogenic mechanism for alumina-based thermal insulators}

\section{Corrected Version}

\section{Original Version at the facilities of the University}

Dissertation submitted to the Materials Science and Engineering Graduate Program at University of São Paulo as a requirement for the Degree of Master of Science.

Concentration Area: Materials Development, Characterization and Application.

Supervisor: Prof. Dr. Rafael Salomão

\section{São Carlos}


I AUTHORIZE THE TOTAL OR PARTIAL REPRODUCTION OF THIS WORK, THROUCH ANY CONVENTIONAL OR ELECTRONIC MEANS, FOR STUDY AND RESEARCH PURPOSES, SINCE THE SOURCEIS CITED.

Catalog card prepared by Patron Service at "Prof. Dr. Sergio Rodrigues Fontes" Library at EESC/USP

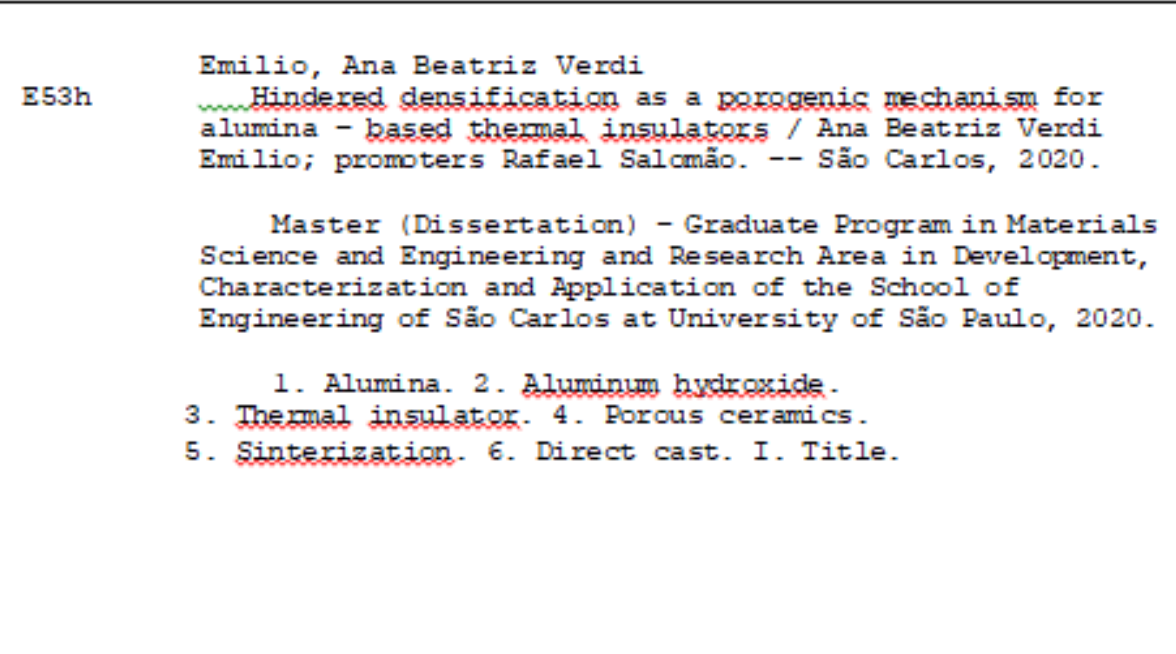

Elena Luzia Palloni Conçalves - CRB 8/4464 


\section{FOLHA DE JULGAMENTO}

\section{Candidala: Engenheira ANA BEATRIZ VERDI EMILOO.}

Titulo da dissertação: 'Densíficaçôo dificultada como mecanismo porogénico para obtençâo de isolantes témicos á base de alumifa".

Dato da delesa: 16/11/2020.

\section{Comissâo Julgadora}

Prof. Asscciado Rafacl Salomōo

\section{(Orienlador)}

[Escola de Engenharia de São Carlos/EESC)

Profa. Dra. Eliona Cristina da Silva Riga

|Faculdade de Zootecnia e Engenharia de Alimentos/FZEA-USP)

Dr. Marcelo Dezena Cabreicon

(Innovare Inteligência em Cerâmica Ltda)
Resultado

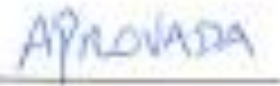




\section{With Gratitude}

To my parents, Célia e João, for supporting and love.

My sisters, Heloisa e Maria Leticia, for conversations and incentive

My boyfriend, Pedro, for help, advice and affection. 



\section{Acknowledgments}

To Graduate Program in Materials Science and Engineering of São Carlos School of Engineering (EESC/USP) for the opportunity to take the master's course and the Materials Engineering Department (SMM) for the use of facilities.

For my advisor, Prof. Dr. Rafael Salomão, for trusting me and my work, all support, and, mainly, for contribution with my training since undergraduate until master.

To funding agencies by the financial support provided. Coordenação de Aperfeiçoamento de Pessoal de Nível Superior (CAPES), financial code 001, Fundação de Apoio à Pesquisa do Estado de São Paulo (FAPESP) (2010/19274-5) and Conselho Nacional de Desenvolvimento Científico e Tecnológico (CNPQ) (470981/2011-3; 306036/2011-8)

To Almatis (Brazil and Germany) for raw-materials donation.

To my colleagues of the research group SIMMaC (Integrated Solutions for Manufacturing and Ceramic Materials), José Sakihama PhD, Mirian Kawamura MSc, Natalia Spera MSc, Paola Barbosa and, in special, Leandro Fernandes $\mathrm{PhD}$, who welcome and supported me with samples preparations, doubts and, also, conversations and advice.

To department's technicians and administrative personnel, in special, João Bernardi and Pedro di Lorenzo, for help carrying out the tests performed, and Victor Barioto, for helping with bureaucratic issues.

For my parents, João Francisco Emilio and Célia C. Verdi Emilio, for love me and help me to achieve my goals; my sisters Heloisa H. Verdi Emilio e Maria Leticia Verdi Emilio, for supporting me in my decisions; and my boyfriend, Pedro Bonella, for advice, patience and love.

For my friends, Bruna Galli, Cintia Rodrigues, Cíntia Consonni, Giovana F. Leite, Isabella Magalhães, Jéferson Pedrosa, Juliana Pereira, Karoline Musquiari, Raquel Russolo for supporting me even at a distance.

For my department collegues Camila Teixeira, Écio Bosi, Larissa Proença, Lucas Fuscaldi, Lucas Soares and Pedro Bethônico. 



\begin{abstract}
EMILIO, A. B. V. Hindered densification as a porogenic mechanism for alumina-based thermal insulators. 2020. Master (Dissertation) - São Carlos School of Engineering, University of São Paulo, São Carlos, 2020.
\end{abstract}

Porous ceramics for application as high-temperature thermal insulators $\left(600^{\circ} \mathrm{C}-1600^{\circ} \mathrm{C}\right)$ have been investigated as an alternative to the use of block and blankets of ceramic fibers. They present potential for such application because of the combination of low conductivity of porous structures (less than $5 \mathrm{~W}(\mathrm{~m} . \mathrm{K})^{-1}$ at $1200^{\circ} \mathrm{C}$ ) with the refractoriness of ceramics. However, they do not resist densification as well as fibers after long periods at high temperatures. The presence of porosity reduces thermal conduction, because pores are filled with gases with low conductivity and also provoke scattering of photons, which are responsible for radiation process that occurs at high temperatures. To be effective it is also necessary that the pores be closed and small ( $<4 \mathrm{~mm}$ diameter), in order to avoid the convection process. To maintain porosity and stability at high temperatures, it is necessary that the main sintering mechanism be surface diffusion, because it does not promote significant densification. This work is based on the principles of sintering and heat conduction to propose a novel porogenic mechanism. Thus, this work studied the compacting of pre-sintered aluminum hydroxide $\left(\mathrm{Al}(\mathrm{OH})_{3}\right)$ because the particles obtained have internal pores, intrinsically resistant to densification due to their low surface area and curved shape. Three compaction methods were used: isostatic and uniaxial pressing and direct cast. The pressed samples resulted in lower values of total porosity at $1600^{\circ} \mathrm{C}(61.5 \%$ for uniaxial and $56.3 \%$ for isostatic $)$, as they produced broken filaments during the application of pressure which increased the compaction of the particles and facilitated densification. The samples obtained by direct molding, on the other hand, did not compact well because the main diffusion mechanism was surface diffusion, maintaining porosity at high levels (74.4\%). The physical properties obtained such as flexural strength (3.75 MPa) and rigity (4.57 GPa) are satisfactory for the application as thermal insulator $(0.5-1 \mathrm{MPa}$ and $2 \mathrm{GPa}$, respectively). In addition, the samples showed low thermal conductivity $\left(0.49 \mathrm{~W} \cdot \mathrm{m}^{-1} \cdot{ }^{\circ} \mathrm{C}^{-1}\right.$ to $\left.1400^{\circ} \mathrm{C}\right)$, low shrinkage after sintering $\left(11,92 \%\right.$ at $\left.1600^{\circ} \mathrm{C}\right)$ and high resistance to thermal shock due to the low expansion coefficient obtained $\left(5.710^{-6} \cdot{ }^{\circ} \mathrm{C}^{-1}\right.$ at $\left.1200^{\circ} \mathrm{C}\right)$.

Key words: Alumina. Aluminum hydroxide. Thermal insulator. Porous ceramics. Sinterization. Direct cast. 



\section{RESUMO}

EMILIO, A. B. V. Densificação dificultada como mecanismo porogênico para obtenção de isolantes térmicos à base de alumina. 2020. Dissertação (Mestrado) -Escola de Engenharia de São Carlos, Universidade de São Paulo, São Carlos, 2020.

Materiais porosos para isolantes térmicos de alta temperatura $\left(600^{\circ} \mathrm{C}-1600^{\circ} \mathrm{C}\right)$ tem sido investigados como uma alternativa ao uso de blocos e cobertores de fibras cerâmicas. Eles apresentam potencial para tal aplicação por combinar a baixa condutividade das estruturas porosas (menos que $5 \mathrm{~W}(\mathrm{~m} . \mathrm{K})^{-1}$ a $1200^{\circ} \mathrm{C}$ ) com a refratariedade das cerâmicas. No entanto, não resistem tão bem a densificação quanto as fibras depois de longos períodos a altas temperaturas. Sabe-se que a presença de porosidade reduz a condução, uma vez que os poros apresentam gases com baixa condutividade em seu interior e provocam o espalhamento de fótons os quais são responsáveis pelo processo de radiação. Para a porosidade ser efetiva é necessário que os poros sejam fechados e com tamanho reduzido (diametro $<4 \mathrm{~mm}$ ), a fim de evitar o processo de convecção. Para manter a porosidade e a estabilidade a altas temperaturas é necessário que o principal mecanismo de sinterização seja a difusão superficial, já que não promove densificação significativa. Este trabalho se baseia nos princípios de sinterização e de condução de calor para propor um novo mecanismo. Sendo assim, estudou a compactação de hidróxido de alumínio $\left(\mathrm{Al}(\mathrm{OH})_{3}\right)$ pré-sinterizado a $1500^{\circ} \mathrm{C}$, pois as partículas obtidas apresentam poros internos intrinsicamente resistentes a densificação por terem baixa área superficial e formato curvado. Foram utilizados três métodos de compactação: prensagens isostática e uniaxial e moldagem direta. As amostras prensadas resultaram em menores valores de porosidade total a $1600^{\circ} \mathrm{C}(61.5 \%$ para uniaxial e $56,3 \%$ para isostática), pois tiveram filamentos quebrados durante a aplicação de pressão o que aumentou a compactação das partículas e facilitou a densificação. Já as amostras obtidas por moldagem direta não compactaram bem por terem como mecanismo principal de sinterização a difusão superficial, mantendo a porosidade em níveis elevados (74.4\%). As propriedades físicas obtidas tais como resistência a flexão (3.75 $\mathrm{MPa}$ ) e rigidez (4.57 GPa) são satisfatórios para o que é requerido para a aplicação (0.5-1 $\mathrm{MPa}$ e $2 \mathrm{GPa}$, respectivamente). Além disso, as amostras apresentaram baixa condutividade térmica $\left(0.49 \mathrm{~W} \cdot \mathrm{m}^{-1} \cdot{ }^{\circ} \mathrm{C}^{-1}\right.$ to $\left.1400^{\circ} \mathrm{C}\right)$, baixa retração linear $\left(11,92 \%\right.$ at $\left.1600^{\circ} \mathrm{C}\right)$ e alta resistência ao choque térmico devido ao baixo coeficiente de expansão obtido $\left(\left(5.710^{-6} \cdot{ }^{\circ} \mathrm{C}^{-1}\right.\right.$ a $\left.1200^{\circ} \mathrm{C}\right)$.

Palavras chave: Alumina. Hidróxido de alumínio. Isolante térmico. Cerâmica porosa. Sinterização. Moldagem direta. 



\section{LIST OF ILLUSTRATIONS}

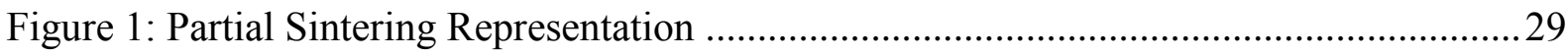

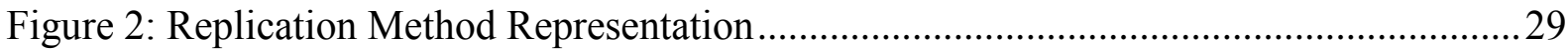

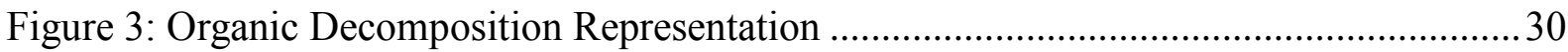

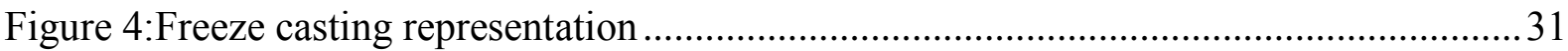

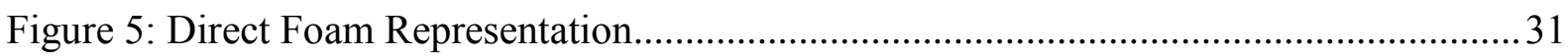

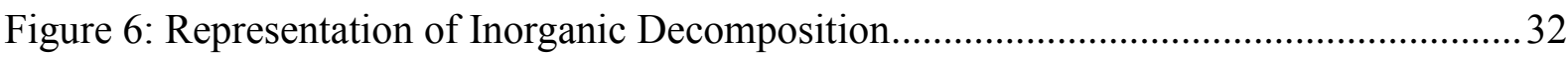

Figure 7: Schematic showing three spherical particles and the various mass transport paths that

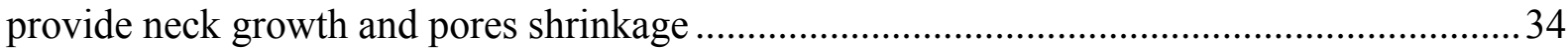

Figure 8: Grains with less than six sides are concave and with more than six convex ............35

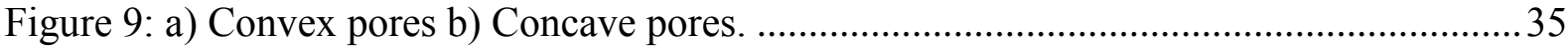

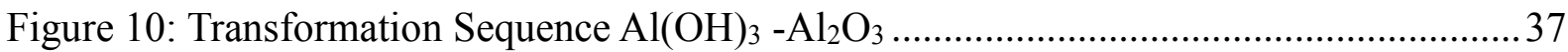

Figure 11: Schematic representation of the process employed for the production of coral-like

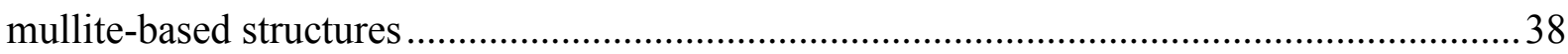

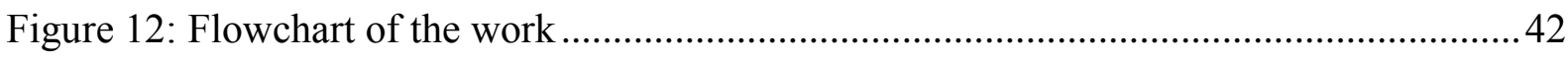

Figure 13: Devices used in processing a) paddle-mixer b) metallic mold for uniaxial pressing c) polymeric mold for direct casting

Figure 14: Pressed samples comprised by a) as-received aluminum hydroxide and b) aluminum hydroxide previously calcined at $500^{\circ} \mathrm{C}$. Both samples were sintered at $1500^{\circ} \mathrm{C} / 3 \mathrm{~h}$.............50

Figure 15: SEM images of a) as-received $(\mathrm{AH})$ and b) $\mathrm{Al}(\mathrm{OH})_{3}$ sintered at $1500^{\circ} \mathrm{C}(\mathrm{SAH}) \ldots 52$ Figure 16: Samples directly cast with a) water and hydratable alumina and with b) colloidal alumina and hydratable alumina after demolding and drying .....

Figure 17: Schematic representation of the production and processing of coral-like structures.

Figure 18: Total Porosity obtained for direct cast, uniaxial and isostatic pressing methods....54 Figure 19: SEM images of filaments broken of pressed green samples a) uniaxial b) isostatic

Figure 20: Mechanical Properties a) Flexural Elastic Modulus b) Flexural Modulus of Rupture c) Linear Variation After Sintering. 57

Figure 21:SEM Image of fracture cross-sections of green-dried and sintered samples $\left(1100^{\circ} \mathrm{C}\right.$, $1300^{\circ} \mathrm{C}, 1500^{\circ} \mathrm{C}$ and $1600^{\circ} \mathrm{C}$ ) prepared using different compacting methods. 58

Figure 22: a) Thermal Linear Variation b) Thermal Linear Variation Rate for direct cast and 


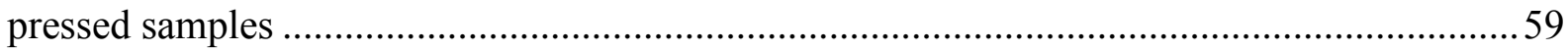

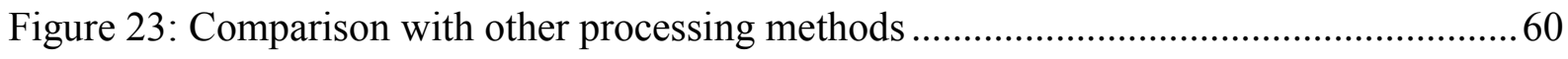

Figure 24: Dilatometric analysis of sintered samples $\left(1600^{\circ} \mathrm{C}\right)$ a) Thermal Linear Variation b)

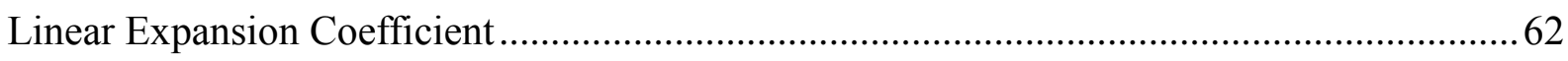

Figure 25: Thermal Conductivity of direct cast sample of this work compared to other insulators

materials 63 


\section{LIST OF TABLES}

Table 1: Previously thermal treatment performed in powders ....................................... 43

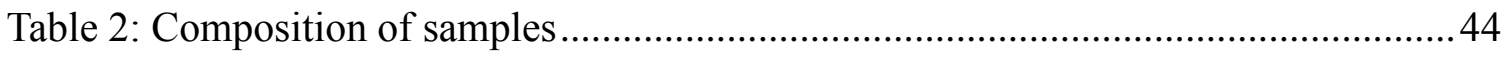

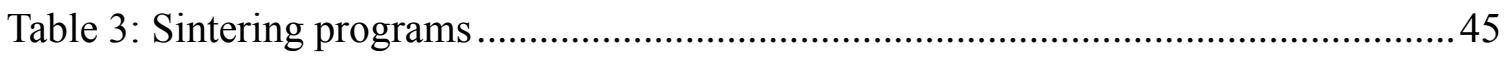

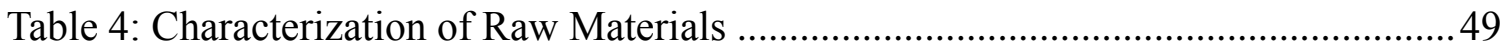

Table 5: Average Linear Expansion Coefficient Results $\left(300^{\circ} \mathrm{C}-1200^{\circ} \mathrm{C}\right)$........................61 



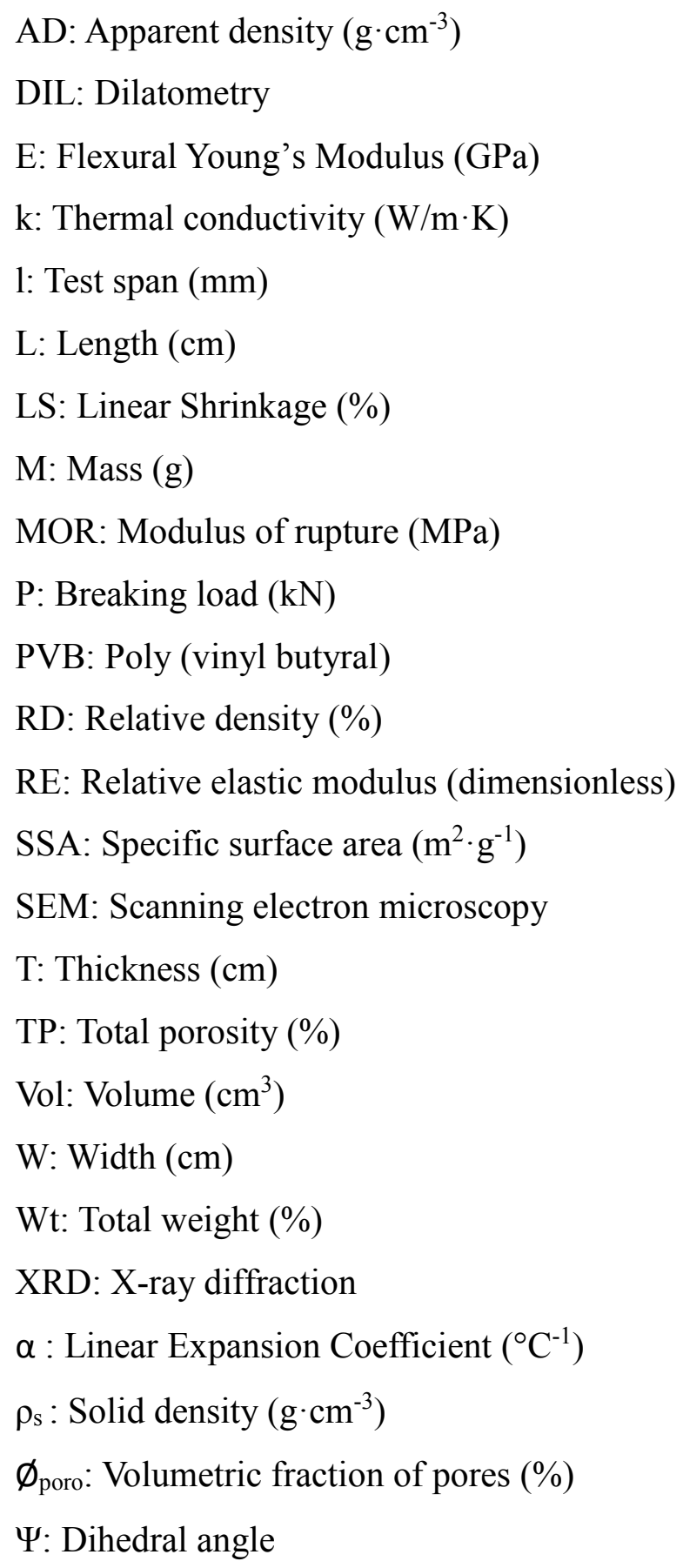





\section{TABLE OF CONTENTS}

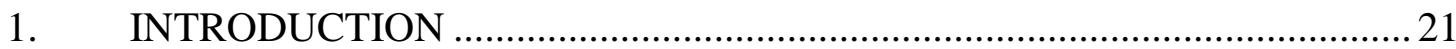

1.1. High-Temperatures Thermal Insulators: General Aspects ..............................2 21

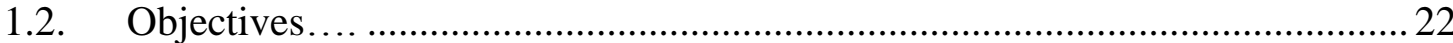

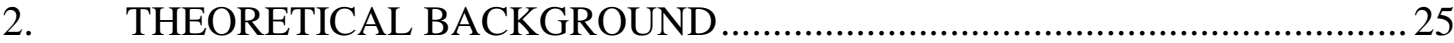

2.1. Heat Conduction mechanisms and effects of ceramic microstructure ...............25

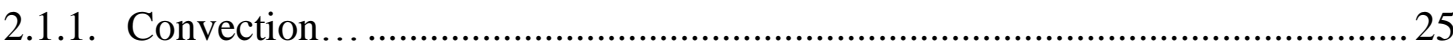

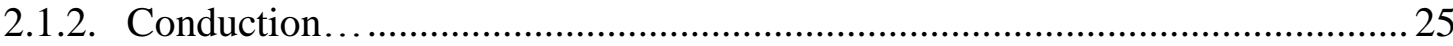

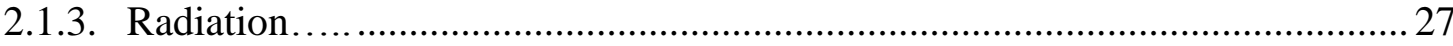

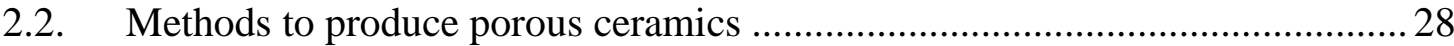

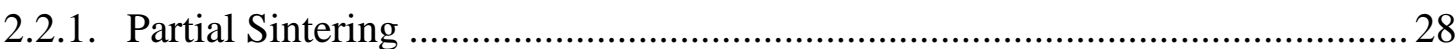

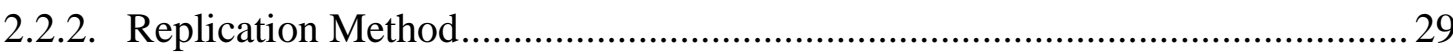

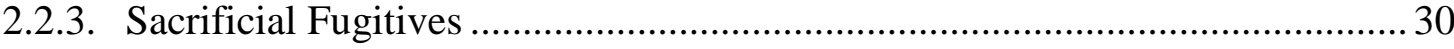

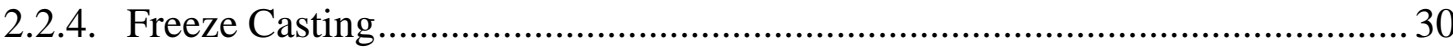

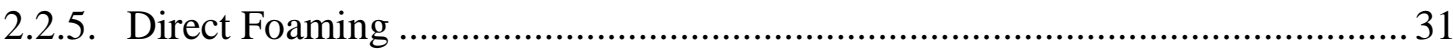

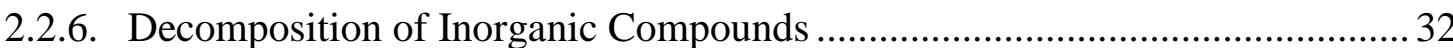

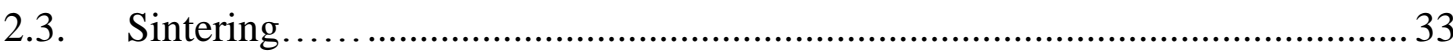

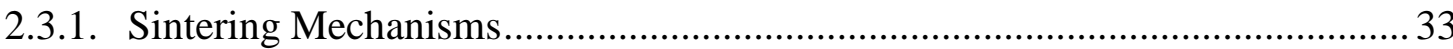

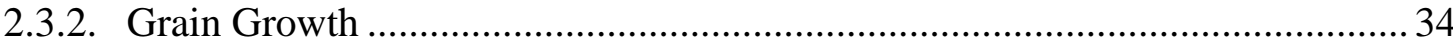

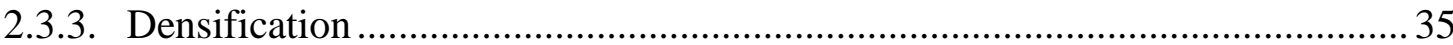

2.4. Aluminum Hydroxide Dehydroxylation as a Porogenic Mechanism ................ 36

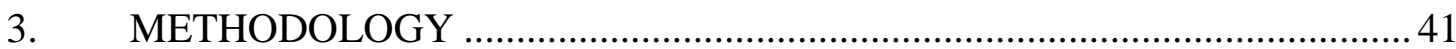

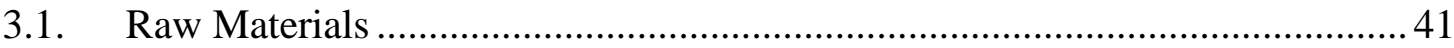

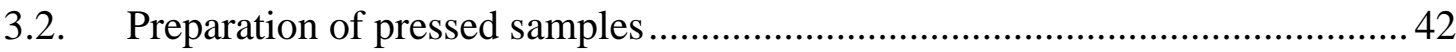

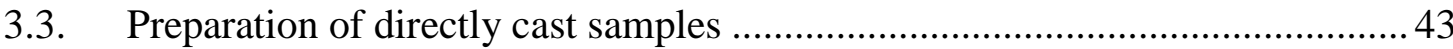




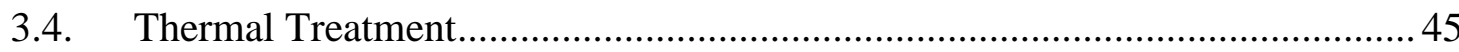

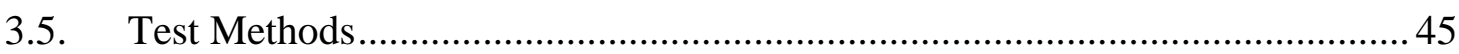

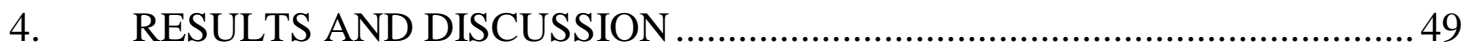

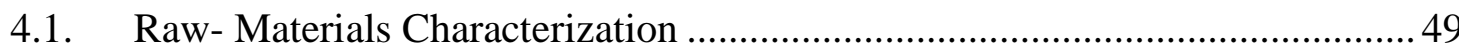

4.2. Preliminary tests with as-received, calcined and sintered aluminum

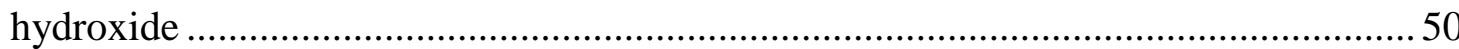

4.3. Preliminary test of the direct cast with water and colloidal alumina.................52

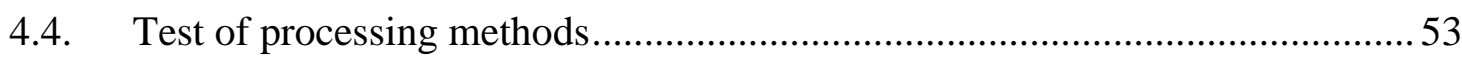

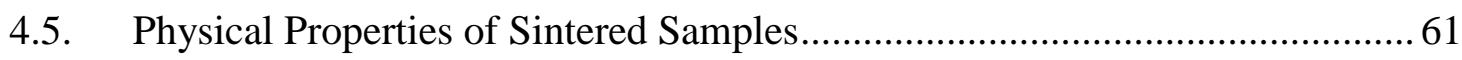

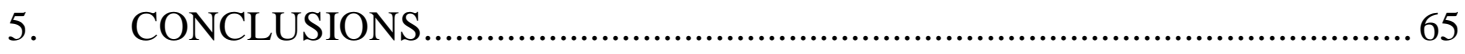

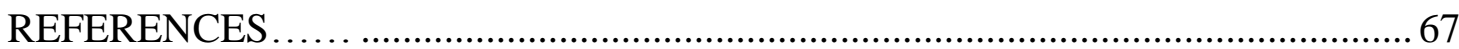





\section{INTRODUCTION}

\subsection{High-Temperatures Thermal Insulators: General Aspects}

Steelmaking, petrochemical, cement and lime industries are responsible for a significant part of the worldwide energy consumption due to their intensive use of high-temperature processes $\left(600-1600^{\circ} \mathrm{C}\right)$. China and United States, which are world's biggest consumers of energy, destinate large percentages of their energy consumption to petrochemical industry, 23 $\%$ and $24 \%$ respectively. Other sectors with high energy expenditure are steelmaking ( $26 \%$ in USA and $5.68 \%$ in China) and cement (2\% in USA). [1,2]. Materials of low thermal conductivity have been studied for applications as thermal insulators to prevent unnecessary loss or exchange of heat, increasing energy efficiency. Besides, better thermal insulation can directly contribute to reduce greenhouse effect because it can significantly decrease the consumption of fossil fuels.

Blocks of compacted ceramic fibers have been widely used as high-temperature thermal insulators because they consist of a medium formed by a fiber skeleton with air filling the spaces among them, presenting low densities $\left(10-100 \mathrm{~kg} / \mathrm{m}^{3}\right.$ ) and high porosity (greater than $80 \%$ ) $[3,4]$. The most used materials to produce inorganic fibers are alumina, glass and basaltic rock and their selection must weigh the maximum temperature of work and the melting point and chemical resistance of fibers [4,5]. However, such fibers have high potential of being hazard due to powdered emission, during installation, use, and disposal [6]. Besides, above $1000^{\circ} \mathrm{C}$, the energy transfer by radiation becomes the main heat loss mechanism, and fibers tend to lose efficiency as isolators due to their high transparency[7].

Therefore, microporous monolithic ceramics are an interesting alternative for such application because they combine low thermal conductivity of porous structures (less than 5 $\mathrm{W}(\mathrm{m} . \mathrm{K})^{-1}$ at $\left.1200^{\circ} \mathrm{C}\right)$ with the high refractoriness of ceramics. Many studies were carried out about the processing routes of porous ceramics, such as foam addition [8-12], organic incorporation [13,14], inorganic decomposition [15-17] and in situ formation of porous compounds such as mullite $\left(\mathrm{Si}_{2} \mathrm{Al}_{16} \mathrm{O}_{13}\right)$ [18], calcium hexaluminate $\left(\mathrm{CA}_{6}\right)$ [19,20] and magnesium aluminate spinell $\left(\mathrm{MgAl}_{2} \mathrm{O}_{4}\right)$ [21,22]. However, they do not withstand densification as well as fibers after longs periods of exposure at high temperatures. For this reason, to obtain porous materials that are resistant to densification at temperatures above $1000^{\circ} \mathrm{C}$, firstly it is necessary to understand the heat transfer and sintering mechanisms, to propose the best ways to hinder densification and obtain components of suitable characteristics to become an insulator.

Different from other studies that focused on incorporation of porogenic agents into a matrix 
or phase changes to obtain a porous structure, this study proposed a novel hindering densification mechanism based on the intrinsic characteristics of the precursor raw materials.

$\mathrm{Al}(\mathrm{OH})_{3}$ was chosen as starting raw material because, during dehydroxylation, its particles become highly porous due to the density increase and micro-cracking. At higher temperatures, such mesopores evolve to filamentous macroporous structures known as coral-like, which present intra-particle pores. Due to their low surface area and curved shape, these pores are intrinsically resistant to densification [17]. Thus, if these particles could be controlled consolidate without losing their internal porosity, they would provide conditions to hinder densification and possibly allow the production of a long-service-life insulator.

\subsection{Objectives}

\section{Main Objective}

The analysis of the published literature indicated that, to produce highly porous densification-resistant ceramic structures suitable for thermal insulation, the following advices must be followed:

- The simple decomposition of hydroxylated precursors is the most suitable method to produce such structures in large volumes and at competitive costs. However, the microstructures attained might not be the most stable ones.

- The dominant sintering mechanism must be based on surface diffusion phenomena to minimize densification.

- Consolidation methods based on pressing will most likely produce less porous structures in comparison to direct casting of suspensions, due to the lower initial content of pores and to the greater driving force for sintering.

- Previously sintered $\mathrm{Al}(\mathrm{OH})_{3}$ and other coral-like particles are promising raw materials for such application.

Therefore, based on these considerations, the present work aimed to obtain porous ceramics structures of high densification resistance for application as thermal insulators that show total porosity levels above $50 \%$ [7], average pore size ranging between 0,5-5 $\mu \mathrm{m}$ [23], flexural elastic modulus above 2GPa [24], flexural strength above $0.5-1 \mathrm{MPa}$ [24], linear shrinkage lower than $15 \%$ after sintering at $1500^{\circ} \mathrm{C}$ and thermal conductivity below $2 \mathrm{~W}(\mathrm{~m} \cdot \mathrm{K})^{-}$

${ }^{1}$ at temperatures above $1100^{\circ} \mathrm{C}$. Such properties levels were previously determined in author's research group as adequate to present a suitable behavior as thermal insulators, comparable or superior to conventional insulators [24]. The hindered densification mechanism was used to 
produce such structures using previously sintered $\mathrm{Al}(\mathrm{OH})_{3}$ as raw-material.

\section{Specific Objectives}

Comparison amongst three shaping methods (isostatic pressing, uniaxial pressing, and direct cast) and their correspondent evolution of microstructure and physical properties (total porosity, flexural strength, rigidity, pores' size distribution, thermal conductivity, dimensional stability) development during sintering at different temperatures $\left(1100^{\circ} \mathrm{C}, 1300^{\circ} \mathrm{C}, 1500^{\circ} \mathrm{C}\right.$, $\left.1600^{\circ} \mathrm{C}\right)$ 


\section{THEORETICAL BACKGROUND}

\subsection{Heat Conduction mechanisms and effects of ceramic microstructure}

Heat conduction is observed when there is a difference of temperature between two points in a substance, and heat is transferred from high to low-temperature regions until thermal equilibrium is reached [25]. In solid materials, heat conduction may occur by means of three mechanisms, which can also occur simultaneously: convection, conduction, and radiation.

\subsubsection{Convection}

Convection takes place through the simultaneous transport of mass and energy from one place to another by a moving fluid [3]. The governing equation of heat convection behavior is Newton's law (Equation 1):

$$
q_{h}=h A\left(T_{s}-T_{f}\right)
$$

where $\mathrm{q}_{\mathrm{h}}$ is the convective heat rate on surface $(\mathrm{W}), \mathrm{h}$ is the heat transfer coefficient $\left(\mathrm{W} / \mathrm{m}^{2} \mathrm{~K}\right), \mathrm{A}$ is the cross-section of boundary surface $\left(\mathrm{m}^{2}\right), \mathrm{T}_{\mathrm{s}}$ is the surface temperature $(\mathrm{K})$, and $\mathrm{T}_{\mathrm{f}}$ is the temperature of the surrounding fluid $(\mathrm{K})$.

One example of convection occurrence in steel, cement, and petrochemical industries, is the heat exchange by hot air convection inside the furnaces. In ceramic structures, convection is favored when the pores connect to each other, because it is possible to form a stream current for heat transfer. It occurs more significantly in highly permeable structures and inside pores greater than $4 \mathrm{~mm}$ diameter [4]. Therefore, to avoid this kind of heat transfer, it is important to have a structure with closed pores and reduced pore size. Ceramics obtained by direct foaming with pore size smaller than $50 \mu \mathrm{m}$, for instance, have low permeability, consequently, low internal convection [26]; those prepared by replica method, on the other hand, present higher degree of connections amongst pores and are not suitable to produce insulators [10].

\subsubsection{Conduction}

In conduction, heat transfer occurs by the collision of moving electrons and phonons within a solid body [27]. Phonons are ordered atomic vibrations that transfer energy as they propagate throughout the material's structure. Conduction occurs mainly through them because ceramic materials do not have free electrons, [7].

Thermal conductivity is the property that characterizes the ability of a material to transfer heat, and it is expressed by the Fourier's law (Equation 2). The rate of heat transfer by conduction expressed under a Cartesian coordinate system is: 


$$
\begin{aligned}
& q_{x}=q_{x}{ }^{\prime} A_{x}=-k_{x} A_{x} \frac{\partial T}{\partial x} \\
& q_{y}=q_{y}{ }^{\prime} A_{y}=-k_{\mathrm{y}} A_{y} \frac{\partial \mathrm{T}}{\partial \mathrm{y}} \\
& q_{z}=\mathrm{q}_{\mathrm{z}}{ }^{\prime} \mathrm{A}_{\mathrm{z}}=-\mathrm{k}_{\mathrm{z}} \mathrm{A}_{\mathrm{z}} \frac{\partial \mathrm{T}}{\partial \mathrm{z}}
\end{aligned}
$$

where $\mathrm{q}$ denotes the rate of heat transfer $\left(\mathrm{W} \cdot \mathrm{m}^{-2}\right)$, q' is the heat flux per unit time per unit area, $\mathrm{A}$ is the cross-section areas $\left(\mathrm{m}^{2}\right), \mathrm{k}$ is the thermal conductivity $\left(\mathrm{W} \cdot \mathrm{m}^{-1} \cdot \mathrm{K}^{-1}\right) ; \partial \mathrm{T} / \partial \mathrm{x}$ is the temperature gradient along $\mathrm{x}$-axis, $\partial \mathrm{T} / \partial \mathrm{y} \mathrm{y}$-axis and $\partial \mathrm{T} / \partial \mathrm{z}, \mathrm{z}$-axis $\left(\mathrm{K} \cdot \mathrm{m}^{-1}\right)$. Highly anisotropic materials, such as whiskers and graphite lamella, present significant differences of thermal conductivity depending on the crystallographic direction observed. For polycrystalline ceramics, on the other hand, thermal conductivity occurs as an average value comprised on the contributions of each grain unities.

The presence of pores reduces the conduction of a material, because they contain low conductivity gases and behave as scattering points to phonons [7]. Miranda \& Gil (2012) studied the effect of the pore shape on thermal conductivity and concluded that it becomes more intense as the porosity increases [28].

Materials of complex and asymmetrical crystalline structures have a greater tendency to increase thermal scattering of these lattice waves and, typically, show lower levels of thermal conductivity $[7,29]$. For instance, mullite $\left(3 \mathrm{Al}_{2} \mathrm{O}_{3} \cdot 2 \mathrm{SiO}_{2} ; 7 \mathrm{~W} \cdot \mathrm{m}^{-1} \cdot{ }^{\circ} \mathrm{C}^{-1}\right)$, which has a crystalline structure based on orthorhombic system, presents lower thermal conductivity levels than $\mathrm{Al}_{2} \mathrm{O}_{3}$ $\left(30 \mathrm{~W} \cdot \mathrm{m}^{-1} \cdot{ }^{\circ} \mathrm{C}^{-1}\right)$, magnesium aluminate spinel $\left(\mathrm{MgAl}_{2} \mathrm{O}_{3} ; 15 \mathrm{Wm}^{-1 \circ} \mathrm{C}^{-1}\right)$ and $\mathrm{MgO}\left(49,9 \mathrm{~W} \cdot \mathrm{m}^{-}\right.$ ${ }^{1 .}{ }^{\circ} \mathrm{C}^{-1}$ ) which have structures based on hexagonal and cubic systems, respectively [30,31]. Also, lattice vibration decrease as the difference in atomic weight become greater, as in the case of zirconia $\left(\mathrm{ZrO}_{2}\right)$, that presents a thermal conductivity of $2 \mathrm{Wm}^{-1}{ }^{\circ} \mathrm{C}^{-1}$ which is lower than for simple elementary structures such as $\mathrm{Al}\left(237 \mathrm{~W} \cdot \mathrm{m}^{-1} \cdot{ }^{\circ} \mathrm{C}^{-1}\right)$ and $\mathrm{Cu}\left(401 \mathrm{~W} \cdot \mathrm{m}^{-1} \cdot{ }^{\circ} \mathrm{C}^{-1}\right)[29,30,32]$. On the other hand, diamond presents the highest thermal conductivity levels $\left(3000 \mathrm{~W} \cdot \mathrm{m}^{-1} \cdot{ }^{\circ} \mathrm{C}^{-}\right.$ ${ }^{1}$ ) due to its highly directional framework of very strong covalent bonds, associated with light atomic mass, which produces high phonon frequencies and acoustic velocity [33]. 


\subsubsection{Radiation}

Radiation takes place through the propagation, absorption, and emission of photons which becomes significant at elevated temperatures $\left(>1000^{\circ} \mathrm{C}\right)[34]$ as the intensity of emitted radiation rises [7]. The higher the transmitted energy, the greater the energy flow through the material and the higher its thermal conductivity. Therefore, such thermal conduction mechanism increases at high temperatures. Heat radiation is ruled by Stefan-Boltzmann law of thermal radiation (Eq.3):

$$
q_{r}=\sigma \times \varepsilon \times\left(T^{4}-T_{0}^{4}\right)
$$

where $\sigma$ is Stefan-Boltzmann constant; $\varepsilon$, the surface emission coefficient; $\mathrm{T}_{0}$, the temperature of the environment; $\mathrm{T}$, the temperature of the object emitting or absorbing thermal radiation; and $\mathrm{q}_{\mathrm{r}}$, the incident radiant heat flow per unit area of surface.

Radiation is influenced by the average extinction coefficient $\left(\beta^{*}\right)$, which represents a measurement of microstructure-radiation interaction, preventing its transmission through the material. Part of the energy absorbed by a material can be conducted by phonons or reissued as photons. In ceramics, thermal radiation can be absorbed by ionic polarization, a mechanism at which material's ions resonate with infrared photons, that have similar frequency to the vibration of the structure. The contribution of $\beta_{\mathrm{a}}$ (absorption coefficient) at $\beta^{*}$ decreases at high temperatures for conventional refractory ceramics, because the maximum of thermal radiation emission shift towards wavelengths, which most refractory oxides do not absorb significantly. The emission peak is observed at bands where the free path of the photon in the material is relatively large, which increases the thermal conductivity by radiation. Therefore, at high temperatures, the scattering or impurities absorb thermal radiation better, contributing for extinction and conductivity reduction [7].

In radiation, the presence of defects, such as pores and impurities, scatters the photons and reduce the conductivity of the material [7,35]. The scattering caused by pores or dispersed particles can be expressed by Equation 4:

$$
\beta_{s}=Q_{s} \times N_{s} \times \pi \times r_{s}^{2}
$$

where $\mathrm{Q}_{\mathrm{s}}$ is the scattering efficiency of a single defect, $\mathrm{N}_{\mathrm{s}}$ number of defects, function of volumetric fraction of defects $\left(\mathrm{m}^{-3}\right)$, and $\mathrm{r}_{\mathrm{s}}$ is the defect radius $(\mathrm{m})$. To maximize such scattering and reduce irradiation conduction, it is important that the average pore size at the process temperature should be similar to the wavelength of the emitted thermal radiation [7]. According to theoretical calculations, porous structures containing porosity levels above $50 \%$ and pore sizes between $0.5 \mu \mathrm{m}$ and $4 \mu \mathrm{m}$ are ideal for minimizing heat conduction by this 
mechanism[23].

Based on these considerations, materials for thermal insulation require tailored pore size distribution, geometry and volumetric ratio to provide an optimum performance. Therefore, it is necessary to study the several methods used to produce porous ceramics to identify the most suitable ones.

\subsection{Methods to produce porous ceramics}

Porous ceramics are comprised of a dense matrix containing a dispersed porous phase, that represents more than $50 \%$ of the total volume and their pores can be opened or closed. Pores are considered closed when they are not or are partially connected and there is no contact with the surface. On the other hand, they are named open when are interconnected with the surface [36]. In addition, pores can be also classified in terms of their diameter as macropores $(\mathrm{d}>50$ $\mathrm{nm})$, mesopores $(2-50 \mathrm{~nm})$ and micropores $(\mathrm{d}<2 \mathrm{~nm})[37]$. Besides high temperatures thermal insulators, porous ceramics are also used as filters and bioscaffolds for tissue growth. In these applications, the processing method influences important parameters such as size, shape, distribution and pores connectivity [38].

\subsubsection{Partial Sintering}

One of the most important methods to obtain porous ceramics is partial sintering (Figure 1), in which the heat treatment is interrupted before complete densification [39]. The particles are bonded by surface diffusion or evaporation-condensation, being the mechanical properties dependent on the neck growth. Porosity level and pore size are controlled by adjustments in the particle's size, sintering temperature, time and forming pressure $[39,40]$.

Because such structures may shrink and densify when exposed to high temperatures for a long period, this technique is not the best method for applications as a thermal insulator [38], although it can be used to produce low-temperature filtering elements for water or liquid fuels, for instance. 
Figure 1: Partial Sintering Representation

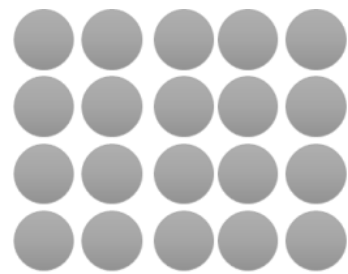

Powder

Formed Body
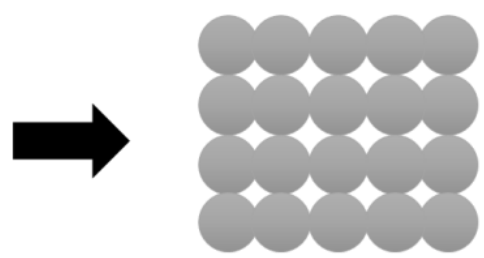

Particle

Bonding/Sintering

Source: [39]

\subsubsection{Replication Method}

The replication method (Figure 2) has as its principle the impregnation of a cellular structure with a suspension of ceramic particles or an organic-inorganic precursor solution. After drying and calcination, the organic material is removed and, after sintering, a porous ceramic with the same morphology of the original material is attained [16,38].

This technique is also not suitable for thermal insulation because it produces open and highly interconnected pores (up to 95\% porosity), of low strength due to cracked and interconnected walls and interconnections [38,41]. Its main use is for the production of highly permeable foundry filters for molten metals.

Figure 2: Replication Method Representation

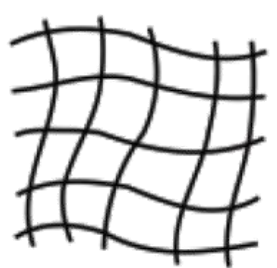

Synthetic or natural template

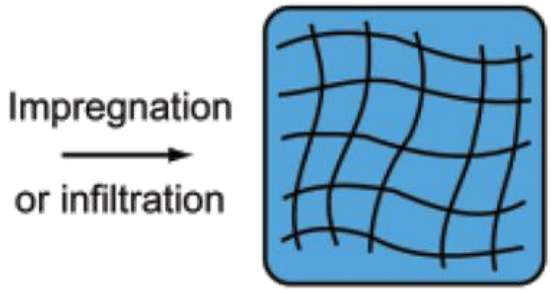

Drying, template removal, sintering

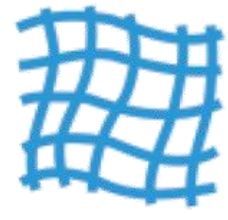

Ceramic suspension or ceramic precursor

Source: [16] 


\subsubsection{Sacrificial Fugitives}

In a variation of the replication process, particles of organic materials are dispersed in the ceramic matrix before shaping. During thermal treatment they are evaporated or burnt and pores are formed in their places (Figure 3) [39]. Usually, the poregenic agents used are polymer beads, organic fibers, undissolved starch, graphite, charcoal, salicylic acid, carbonyl, coal and liquid paraffin [41].

In this case, the porosity level is controlled by the amount of material added and the pore size and shape are tailored by the characteristics of this forming agent [39]. It is also necessary suitable co-dispersion of the ceramic and the agent for obtaining a uniform distribution of pores[41].

Figure 3: Organic Decomposition Representation
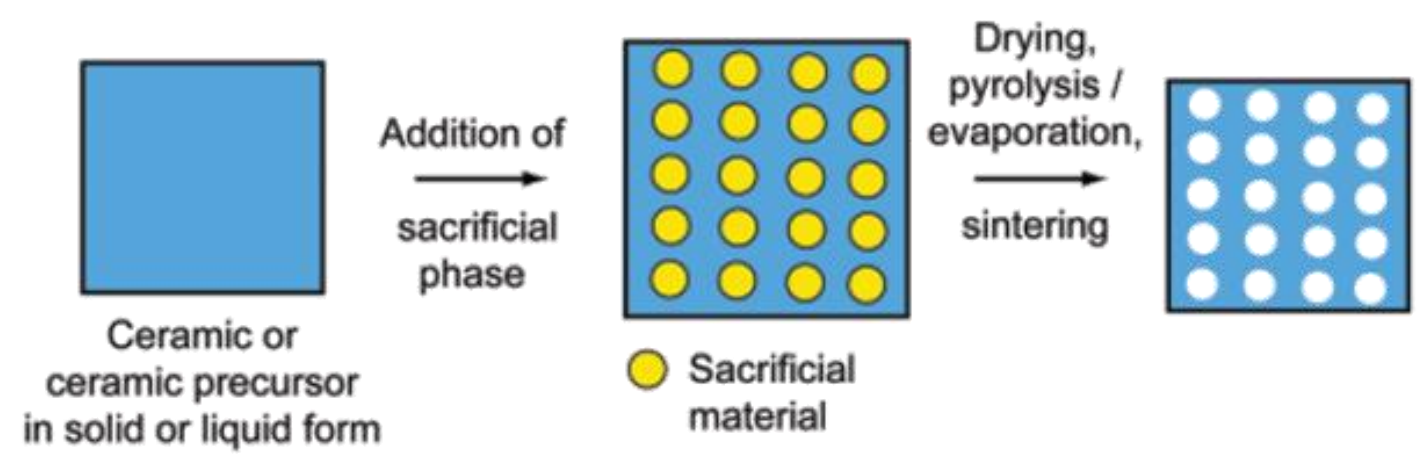

Source: [16]

\subsubsection{Freeze Casting}

Freeze casting (Figure 4) uses a frozen substrate, in which a particle suspension is deposited and the mold favors the nucleation of the material. As solidification occurs, the discarded particles and solutes are concentrated at the interdendritic space. When it is completed, the fluid is removed by sublimation, and the resulting scaffold is sintered to densify and acquire resistance [42].

The pore morphology is almost a replica of the solidified liquid. However, this technique presents difficulties related to the application of sublimation or lyophilization on a large scale or for samples of great dimensions [42]. Due to this, in most cases, it is used to produced porous beads for catalyst support. 


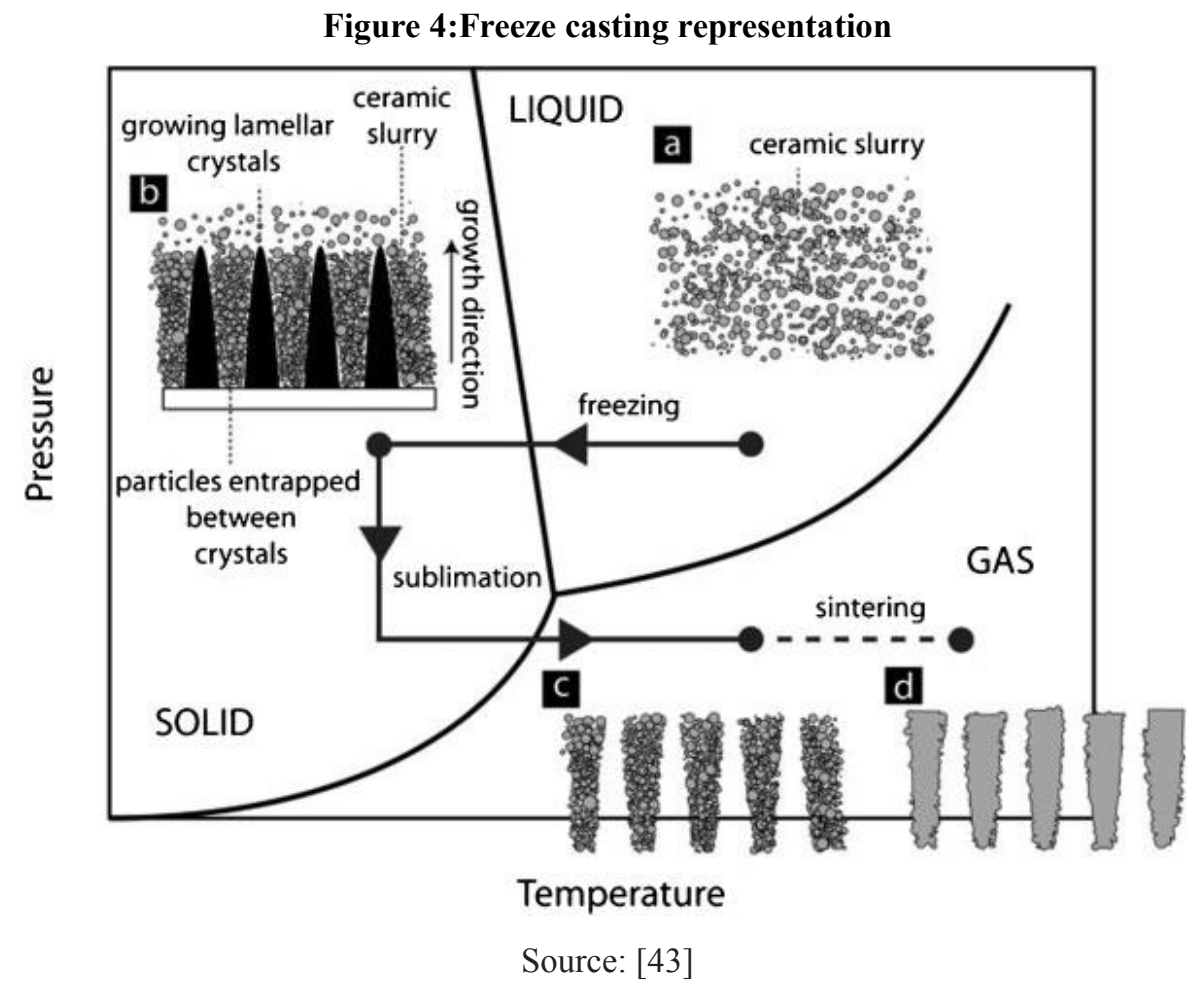

\subsubsection{Direct Foaming}

The direct foam (Figure 5) consists of the incorporation of air or gas into a ceramic particle suspension before consolidation, Thus, after drying the pores have the spherical shape of bubbles [39].

Besides its low-cost and easy fabrication of high-porosity (95\%) ceramics, direct foaming allows the producing of small-pore-sized closed-cell foam [41,44]. However, this technique presents difficulties to maintain control of pores, as gas bubbles tend to coalesce into large pores to reduce their free-energy [39].

Figure 5: Direct Foam Representation

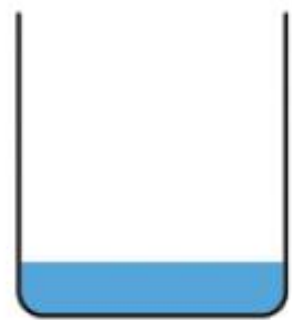

Ceramic suspension or ceramic precursor

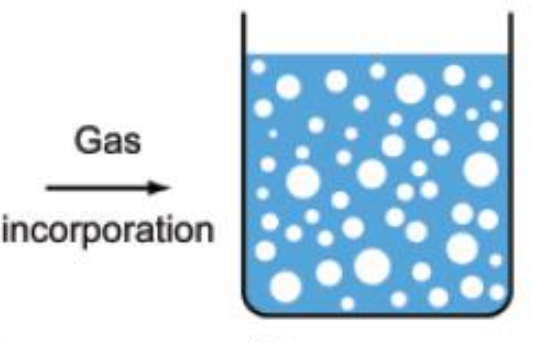

Gas

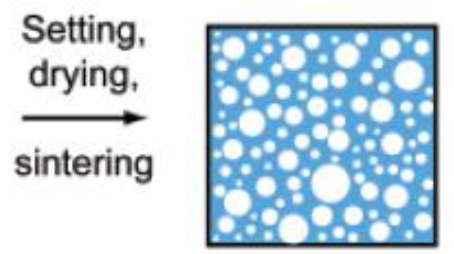

Source: [16] 


\subsubsection{Decomposition of Inorganic Compounds}

The decomposition of inorganic compounds can also be used to obtain porous ceramics. In this case, particles of hydroxylated or carbonated compounds (such as $\mathrm{Al}(\mathrm{OH})_{3}, \mathrm{CaCO}_{3}$ and $\left.\mathrm{Mg}(\mathrm{OH})_{2}\right)$ are incorporated into a matrix composed of dense oxide particles $\left(\alpha-\mathrm{Al}_{2} \mathrm{O}_{3}\right)$ and the shaping is carried out by direct cast or pressing $[18,21,22,45]$. Hydraulic binders, generally oxides that react with water, are used to form hydrated phases, and to strengthen the green ceramic matrix. The decomposition of these hydrates and water evaporation also originate pores [45].

Furthermore, in situ reactions may occur depending on the raw material added to the suspension, allowing obtaining phases of technological interest due to their densificationresistance. Some examples are calcium hexaluminate $\left(\mathrm{CaAl}_{12} \mathrm{O}_{19}\right)$ [20,23,46], mullite $\left(\mathrm{Si}_{2} \mathrm{Al}_{6} \mathrm{O}_{13}\right)[18,47]$ and magnesium aluminate spinel $\left(\mathrm{MgAl}_{2} \mathrm{O}_{4}\right)[21,22]$.

Using $\mathrm{Al}(\mathrm{OH})_{3}$ to obtain porous ceramics has been studied due to the great technological interest, competitive cost, suitable mechanical properties and high chemical resistance. The porous structures are initially comprised by a mixture of $\alpha-\mathrm{Al}_{2} \mathrm{O}_{3}$ and $\mathrm{Al}(\mathrm{OH})_{3}$. When it is submitted to a heat treatment, $\mathrm{Al}(\mathrm{OH})_{3}$ undergoes a phase transformation and generates transition aluminas of higher density and specific surface area (Figure 6) [45].

\section{Figure 6: Representation of Inorganic Decomposition}

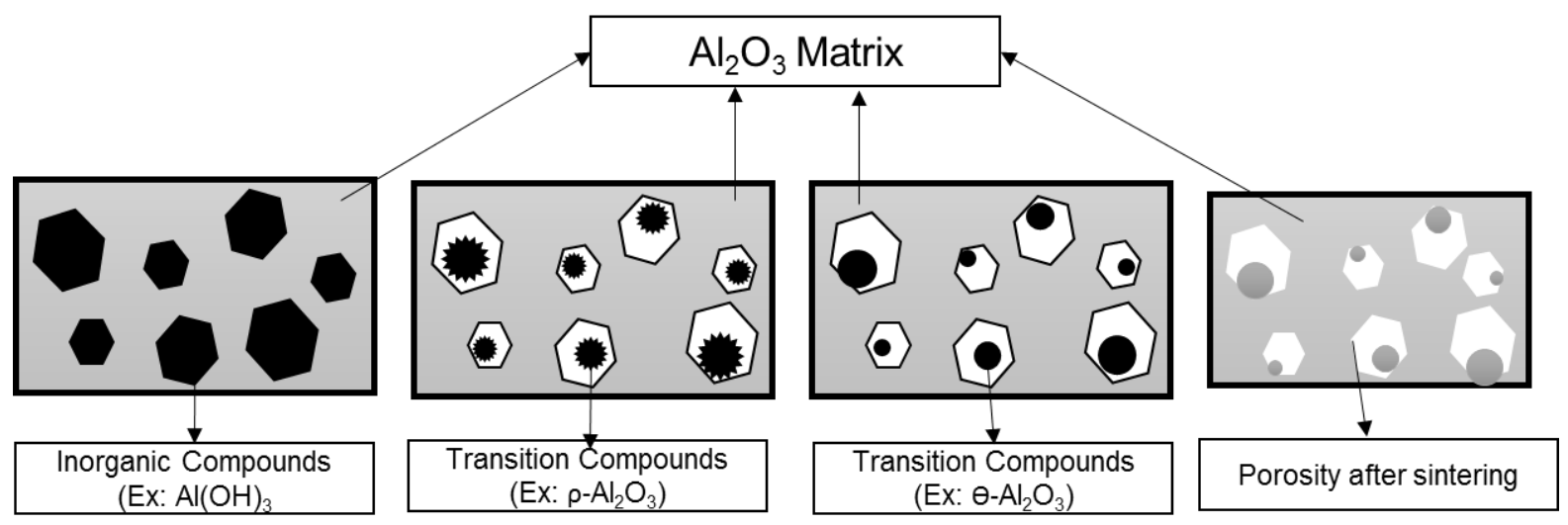

Source: [21]

High-contents of $\mathrm{Al}(\mathrm{OH})_{3}$ (above $50 \%$ ) increases total porosity up to $1100^{\circ} \mathrm{C}$; above this temperature, on the other hand, they favor the densification because of the large amount of transition alumina formed. These alumina particles have high specific surface area, lower particle size and they are more reactive, increasing the driving force for sintering $[17,45]$. 
A critical analysis of these mechanisms of porogenesis indicates that, regarding the production of porous structures for thermal insulation, they all present the same limitation: the exposure of the porous structure to high temperatures for long periods will eventually lead to the densification of pores and reduction of their insulation ability. Therefore, different strategies for pores formation and maintenance are required. To overcome such undesired effects of sintering using a novel porogenic mechanism, initially, it is important to understand the microstructural features involved in this process (diffusion mechanism, particles' necking, densification and pores and grains growth).

\subsection{Sintering}

\subsubsection{Sintering Mechanisms}

Sintering is a thermal treatment associated with high temperatures $\left(0.5 \mathrm{~T}_{\text {Melting }}<\mathrm{T}_{\mathrm{S}}<0.95\right.$ $\mathrm{T}_{\text {Melting }}$ ) responsible for bonding ceramic particles into a solid structure via mass transport at the atomic scale [48] . Its main driving force is the reduction of solid-solid (grain-boundaries and contact particles) or solid-vapor (pores) interfaces and the high surface area of particles [48].

The first stage of this process is the neck growth between particles in contact. The curvature gradient in this region produces the initial decline in specific surface area of the system. Following, as the neck grows, the curvature gradient and the sintering rate decrease, thus changes in pores shape and beginning of grain growth are observed. Lastly, pores become close spheres, resulting in a denser material of high rigidity and strength [49-51].

One of the mechanisms of matter transport is surface diffusion (Figure 7-a), which transfers atoms from convex surfaces (of higher energy) to concave ones (of lower energy), contributing to make pores more spherical and reduce superficial area [52,53]. Evaporation-condensation (Figure 7-b) is responsible for material transport in the vapor phase from one particle surface to another. The direction of transport is similar to diffusion since the equilibrium vapor pressure is lower above concave surfaces than convex. These two mechanisms cause a reduction of specific surface area without significant densification because the origin and destiny of matter are both at particles' surface. Modifications in particles and pores geometry are also common in such conditions $[53,54]$.

As the outer layer of the surface is consumed, bulk and grain boundaries transport mechanisms continue the sintering process. In grain-boundary diffusion (Figure 7-c), the contact points amongst particles provide a source of material to build the neck, leading to grain growth when atoms move through them and densification when they move along with them. In 
this case, densification is observed because the material destined to neck growth is from inner regions of particles [50].

Volume diffusion sintering (Figure 7-d) involves alternating positions between atoms and vacancies when atoms have sufficient energy to jump from their positions. Thus, in powder sintering, the pores are seen as large vacancy clusters, supplying the surrounding solid with them, whereas the solid provides atoms to fill the pore [50].

Plastic or viscous flow mechanisms (Figure 7-e) occur mostly in amorphous materials such as glass, amorphous silica, and polymers that have a viscous character in temperatures above their glass transition and close to $\mathrm{T}_{\mathrm{M}}$. In these cases, the surface tension acts on pores' inner surface producing a pressure gradient that leads to a movement of the material [54].

Figure 7: Schematic showing three spherical particles and the various mass transport paths that provide

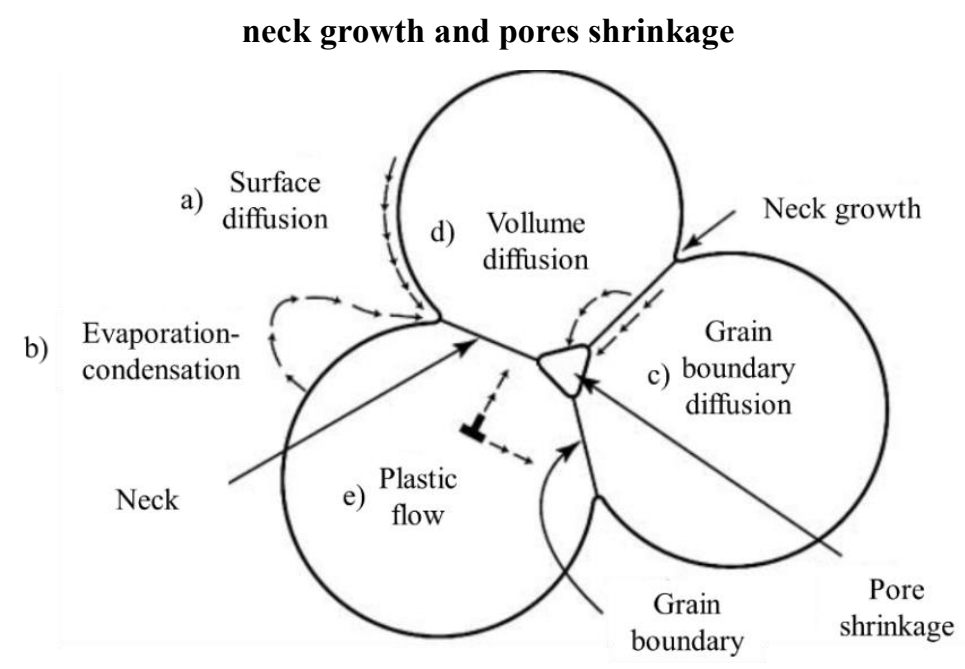

Source: Adapted from [48]

\subsubsection{Grain Growth}

Grain growth is one of the consequences of sintering, and its main driving force is, the surface tensions amongst grain boundaries [55,56]. Grain growth can occur by means of particles coalescence or by mass transfer through the boundaries between them, resulting in the growth of the absorber and contraction of the absorbed. During these processes, it is possible that small grains rebuild their structure according to the crystallographic orientation of the larger one [57].

After compacting and the early stages of necking, grains can present many sides or faces. In a bidimentional representation, those with less than six sides are concave in relation to the 
center of the grain, whereas those with more than six present convex surfaces as illustrated in Figure 8 [56].

Figure 8: Grains with less than six sides are concave and with more than six convex

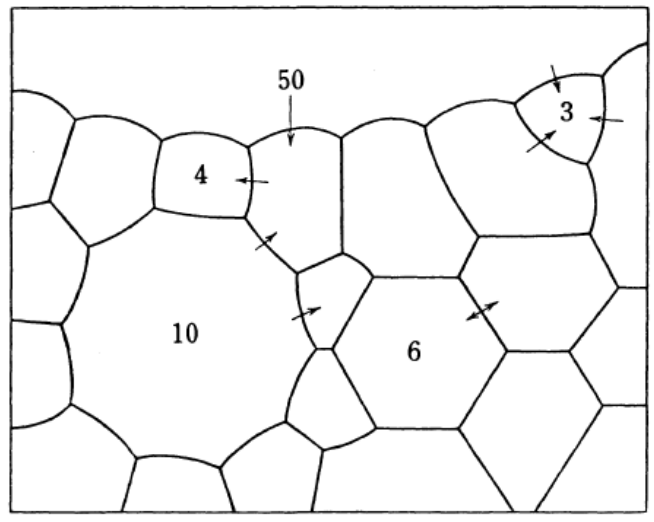

Source: [56]

\subsubsection{Densification}

Densification is another possible result of sintering and occurs by material shrinkage due to pores disappearance. An important concept to understand this phenomenon is the coordination number or the number of touching neighbors, being the critical value $\left(\mathrm{R}_{\mathrm{c}}\right)$ dependent of the dihedral angle $(\psi)[58,59]$. When this value is superior to $R_{c}$, pore configuration is convex (Figure 9-a) and it does not disappear because only concave pores have differential chemical potential that allows material diffusion toward the pore surface. Besides this, convex pores present many sides and reach an equilibrium state before the shrinkage is complete $[57,60]$. Therefore, whereas concave pores tend to disappear, the convex ones tend to grow.

Figure 9: a) Convex pores b) Concave pores.

a)

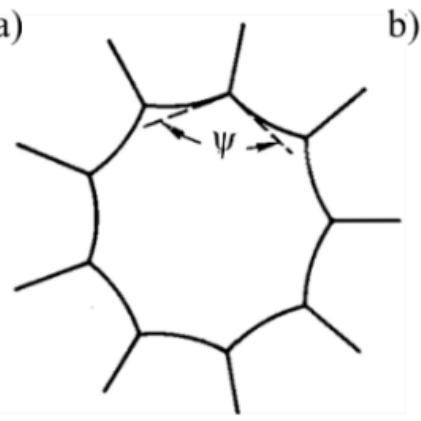

$\mathrm{R}>\mathrm{R}_{\mathrm{c}}$ b)

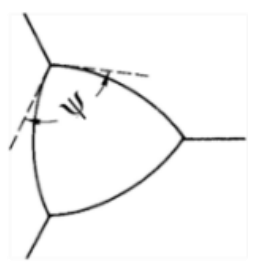

$\mathrm{R}<\mathrm{R}_{\mathrm{c}}$

Source: Adapted from [60] 
During initial sintering, only a fraction of pores is thermodynamically unstable and disappears. However, the coordination number changes along sintering steps and stabilizes pores $\left(\mathrm{R}>\mathrm{R}_{\mathrm{c}}\right)[59,61]$.

Instead of densification, pore growth can occur during sintering. Mechanisms of surface diffusion and evaporation-condensation cause an increase of apparent pore diameter at the initial stages of the process. A wide particle size distribution also leads to pore growth because the fine particles coalesce into large ones, originating, voids through the interstices of these particles, resulting in an increase in average pore size, with little change in total porosity. Lastly, it can also occur if a material suffer phase transformation into a denser one with no shrinkage of the compact [62]. When pore growth exceeds grain growth, the coordination number increases due to coalescence of pores and rearrangement. [61].

\subsection{Aluminum Hydroxide Dehydroxylation as a Porogenic Mechanism}

Aluminum hydroxide can be found in three main forms: gibbsite $\left(\alpha-\mathrm{Al}(\mathrm{OH})_{3}\right)$, bayerite $(\beta$ $\left.\mathrm{Al}(\mathrm{OH})_{3}\right)$ and nordstrandite $\left(\gamma-\mathrm{Al}(\mathrm{OH})_{3}\right)$. Gibbsite is the main constituent of bauxite in nature and, for this reason; its nomenclature is accompanied by the symbol $\alpha$. Its natural crystal habit is usually pseudohexagonal tabular, but grains obtained by Bayer process can be founded as aggregates of tabular and prismatic crystals [63].

During heating, gibbsite $\left(\alpha-\mathrm{Al}(\mathrm{OH})_{3}\right)$ undergoes several transformations in transition aluminas $(\rho, X, K, \eta, \gamma)$ which present larger surface area during heat treatment before reaching the only thermodynamically stable structure of $\alpha-\mathrm{Al}_{2} \mathrm{O}_{3}[15,63-65]$. These transition aluminas refer to the group of partially dehydrated aluminum hydroxides. Its stabilization temperature depends on crystallinity and impurities of starting materials, besides thermal treatment. Due to their high surface area and catalytic activities of their surfaces they can be applied as absorbents, catalysts, coatings and soft abrasives [66]. The sequence of transformations (Figure 10) is not reversible with decreasing temperature. 
Figure 10: Transformation Sequence $\mathrm{Al}(\mathrm{OH})_{3}-\mathrm{Al}_{2} \mathrm{O}_{3}$

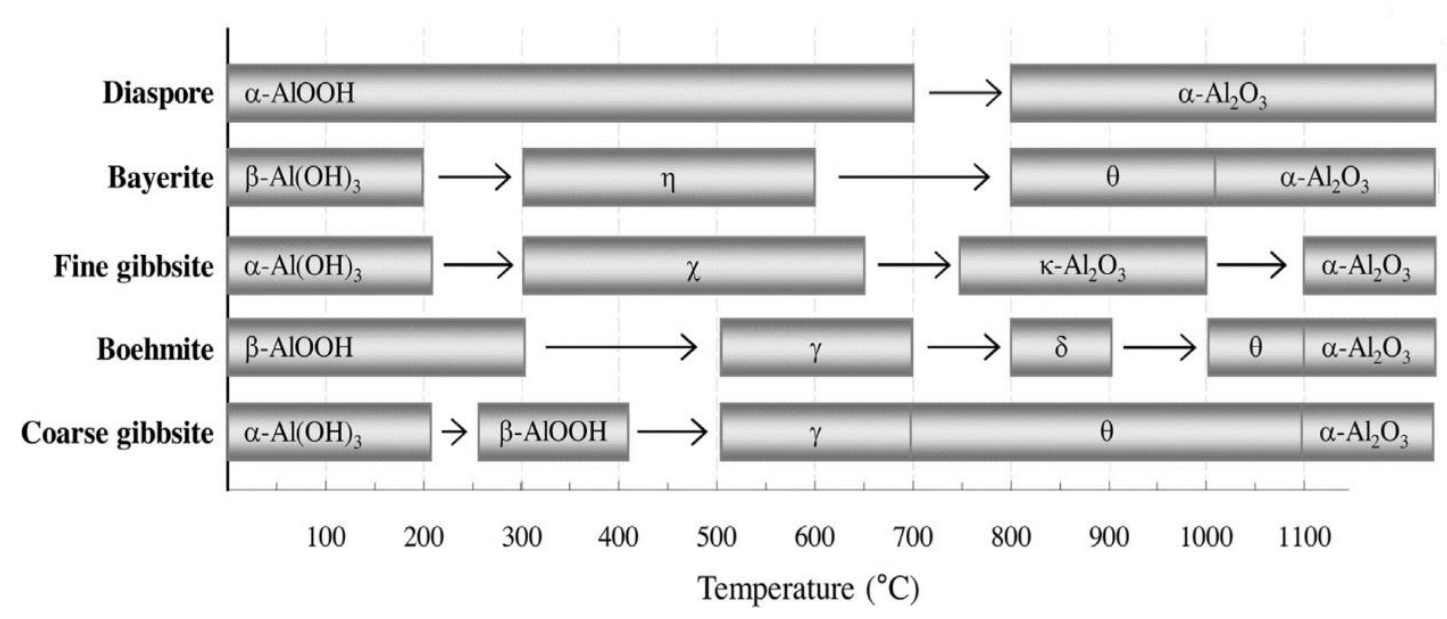

Source: Adapted [67]

Such phases are difficult to detect by XRD because of their defect-rich crystalline structure. Studies on aluminum hydroxide dihydroxylation, however, were carried out to determine these transformations and characteristics as porosity, specific surface area, surface structure, chemical reactivity and the defect crystal structure.

Kogure (1999) [64] observed this process in a transmission electron microscope, at which the changes were occurred in situ by irradiation and heating of an electrons beam. Initially, it occurred a lateral displacement of the gibbsite layers, forming a closed array of anions that became $\mathrm{X}-\mathrm{Al}_{2} \mathrm{O}_{3}$. Later, the $\mathrm{X}-\mathrm{Al}_{2} \mathrm{O}_{3}$ became $\eta$ or $\gamma$ - alumina, through the rearrangement of anions and aluminum atoms, presenting a spinel structure.

Souza et al. (2016) studied the microstructural evolution of aluminum hydroxide over heat treatment temperatures, combining $\mathrm{XRD}$ and $\mathrm{N}_{2}$ adsorption techniques. At $300^{\circ} \mathrm{C}$ hydroxide turned into boehmite $(\beta-\mathrm{AlOOH})$, which has a specific surface area and total pore volume greater than as-received material. Boehmite structure was formed due to the presence of highly pressurized water vapor. At $250-350^{\circ} \mathrm{C}$, the transformation into $\chi-\mathrm{Al}_{2} \mathrm{O}_{3}$ occurred accompanied by and intense mass loss. Above this temperature, the specific surface area decreased, although the pore volume remained constant and cracks began to appear along the basal plane of the particles. At $900^{\circ} \mathrm{C}$, such structures contained cracks perpendicular to the basal plane and $\chi$ $\mathrm{Al}_{2} \mathrm{O}_{3}$ transformed into $\kappa-\mathrm{Al}_{2} \mathrm{O}_{3}$. At $1100^{\circ} \mathrm{C}$ sintering and formation of $\alpha-\mathrm{Al}_{2} \mathrm{O}_{3}$ produced a reduction in pore volume. At $1300-1500^{\circ} \mathrm{C}$ the cracked structures evolved to a more stable cocontinuous morphology [67].

One way of using $\mathrm{Al}(\mathrm{OH})_{3}$ to obtain porous ceramics is in combination with $\alpha-\mathrm{Al}_{2} \mathrm{O}_{3}$ 
particles, such as calcined or tabular alumina. Deng et al. (2001) compared the properties of materials with pure alumina and mixture with $\mathrm{Al}(\mathrm{OH})_{3}(60 \%$ and $90 \%)$ obtaining a porous ceramics by the decomposition of hydroxide, which originates fine $\mathrm{Al}_{2} \mathrm{O}_{3}$ grains with high porosity and when sintered produce strong bonds[68]. Souza et al. (2015) produced porous ceramics by direct cast of a suspension with an $\mathrm{Al}_{2} \mathrm{O}_{3}-\mathrm{Al}(\mathrm{OH})_{3}$ mixture and hydratable alumina as an organic binder, obtaining different levels of porosity and mechanical properties, due to variation of temperature and composition. However, the pores attained are sensitive to high temperatures, due to their small size $(0.1-1 \mu \mathrm{m})$.

Following, Salomão (2017) demonstrated that previously sintered $\mathrm{Al}(\mathrm{OH})_{3}$ particles generate a highly stable porous microstructure at high temperature, which related to its very low surface area, large grains and round pores have shown total porosity levels above $70 \%$ after sintering at $1500{ }^{\circ} \mathrm{C}$. However, due to their imperfect connection amongst particles was necessary a reinforcement with synthetic amorphous silica and mullite (Figure 11) [69].

Figure 11: Schematic representation of the process employed for the production of coral-like mullite-based structures

a) As-received $\alpha=\mathrm{Al}(\mathrm{OH})_{3}$

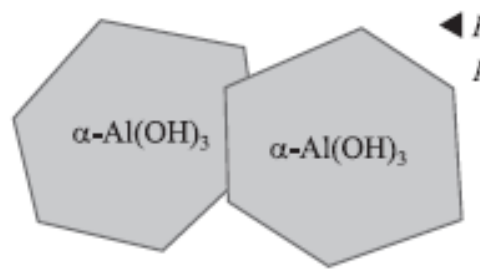

b) During thermal treatment $\left(300-900^{\circ} \mathrm{C}\right)$

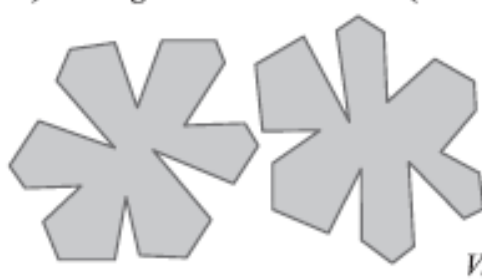

c) $\mathrm{Al}(\mathrm{OH})_{3}$ particles after thermal treatment at $1500^{\circ} \mathrm{C}$

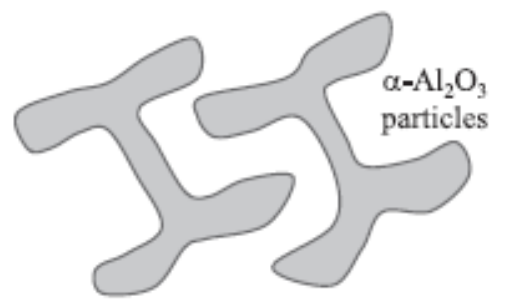

d) Incorporation of SAS's particles ( $O$ )
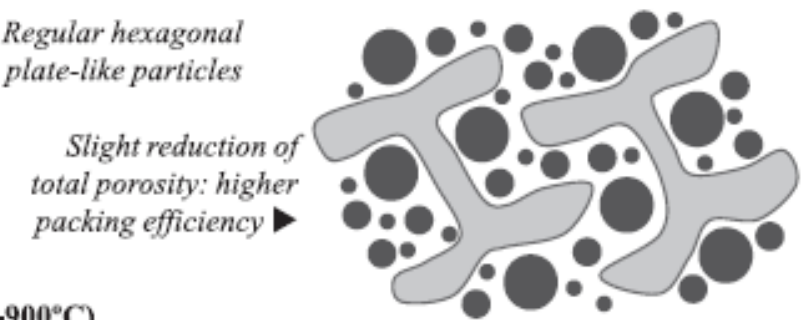

e) During the thermal treatment $\left(<1300^{\circ} \mathrm{C}\right)$

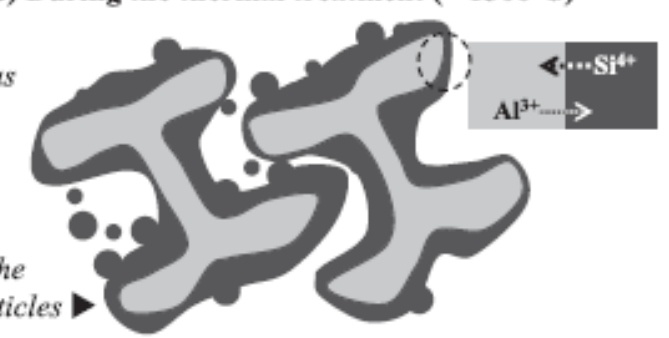

$S A S$ begin to cover the surface of $\mathrm{Al}_{2} \mathrm{O}_{3}$ particles

Formation of transition aluminas $\left(\mathrm{K}-\mathrm{Al}_{2} \mathrm{O}_{3}\right.$ and $\left.\theta-\mathrm{Al}_{2} \mathrm{O}_{3}\right)[11,12]$

\section{Viscous flow of}

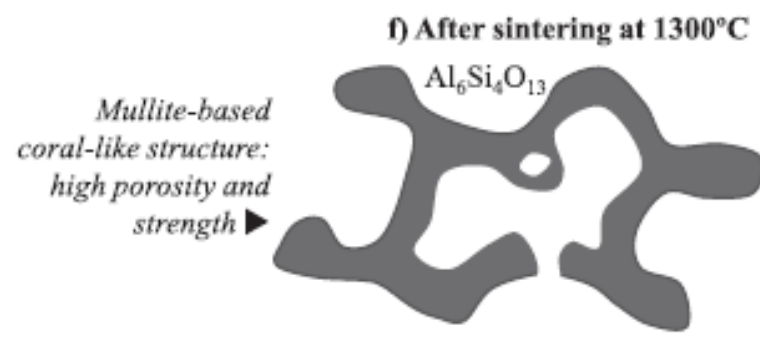

Fonte: [69] 
The difference between this method and partial sintering is the fact that in the second process, sintering is incomplete to maintain the porosity and the pores are inter-particles. Besides this, considering the poorest packaging of equal spheres (simple cubic) a porosity level of just $54 \%$ is possible in the initial phase of partial sintering. On the other hand, the pores in the coral-like particles are stable even when the material is submitted to the sintering temperature of $1500{ }^{\circ} \mathrm{C}$. Besides this, the rounded intra-particle pores present many sides which difficult their densification. 


\section{METHODOLOGY}

\subsection{Raw Materials}

The raw materials and additives used in this work were: a) aluminum hydroxide (AH, $\alpha$ $\mathrm{Al}(\mathrm{OH})_{3}$ or gibbsite, Hydral 710, Almatis, USA) (Figure $12 \mathrm{a}-\mathrm{c}$ ); b) hydratable alumina (HA, $\rho-\mathrm{Al}_{2} \mathrm{O}_{3}$ Alphabond 300, Almatis, USA) c) organic binder (PVB; Poly(vinyl butyral), Butivar 98, Sigma-Aldrich, USA); d) isopropylic alcohol ( $\mathrm{C}_{3} \mathrm{H}_{8} \mathrm{O}$,Synth, Brazil); e) colloidal alumina (AL20, Nyacol, USA). Particles were characterized before being added to suspensions.

The raw materials were previously dried at $120^{\circ} \mathrm{C}$ for $24 \mathrm{~h}$ and characterized using Helium pycnometer method (Ultrapyc 1200e, QuantachromeInstruments, USA) to determine the solid density ( $\rho_{\text {Solid }}$ ), value that is attained as the average of five measurements (Figure 12-D).

Particles' specific surface area was measured using Nitrogen Adsorption Method that uses the mathematical modeling BET (Nova 1200e, Quantachrome Instruments, USA). The $\mathrm{N}_{2}$ used had high purity $(99.999 \%)$ and relative pressure $\left(\mathrm{P} / \mathrm{P}_{0}, \mathrm{P}_{0}\right.$ atmosphere pressure) varying from 0.05 to 0.3 . For this test samples were previously degassed at $200^{\circ} \mathrm{C}$ for $2 \mathrm{~h}$ according to the standard ASTM C1069-09 ("Standard Test Method for Specific Surface Area of Alumina or Quartz by Nitrogen Adsorption") [70].

Their size distribution ( $\mathrm{D}_{50}$ medium size and $\mathrm{D}_{90}$ maximum size) were obtained by the laser diffraction technique in a Zetasier NanoZS (Malvern, USA) equipment, using an aqueous suspension prepared with distilled water and dispersant (ammonium poly(acrylate), Darvan C$\mathrm{N}$, Vanderbilt, USA).

The chemical composition was determined by energy dispersive X-ray spectroschopy (Shimadzu, EDX 720, Japan). The morphology of the particles was observed by field emission gun scanning electron microscopy (FEG-SEM, FEI 7500F, USA). 
Figure 12: Flowchart of the work

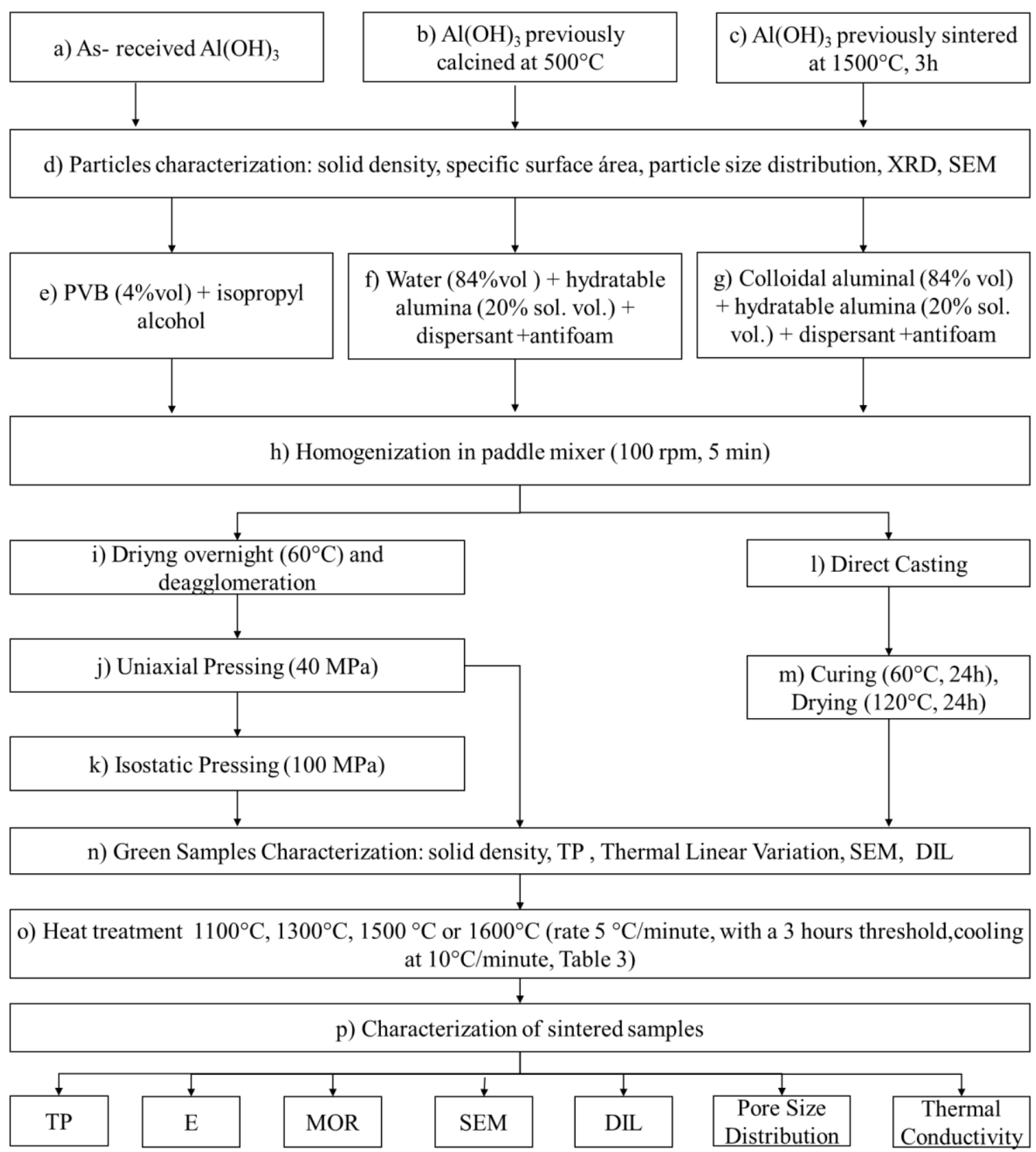

Source: Author

\subsection{Preparation of pressed samples}

Pressed samples were formulated with as-received $\mathrm{Al}(\mathrm{OH})_{3}$ (Figure 12-a), $\mathrm{Al}(\mathrm{OH})_{3}$ calcined at $500^{\circ} \mathrm{C}$ (Figure 12-b) or $\mathrm{Al}(\mathrm{OH})_{3}$ sintered at $1500^{\circ} \mathrm{C}$ (Figure 12- c). Firstly, powders were thermally treated (Table 1 ), thereafter, were incorporated into a $3 \mathrm{wt} \%$ solution previously prepared of poly(vinyl butyral) (PVB, Sigma-Aldrich, USA) dissolved in isopropyl alcohol (Table 1, Figure 12-e). 
Table 1: Previously thermal treatment performed in powders

\begin{tabular}{|c|c|c|c|}
\hline Material & Heating (Step 1) & Heating (Step 2) & Cooling \\
\hline As-received $\mathrm{Al}(\mathrm{OH})_{3}$ & - & - & - \\
\hline $\begin{array}{c}\mathrm{Al}(\mathrm{OH})_{3} \text { calcined at } \\
500^{\circ} \mathrm{C}\end{array}$ & $\begin{array}{c}\text { From room } \\
\text { temperature up to } \\
120^{\circ} \mathrm{C}, 2^{\circ} \mathrm{C} \cdot \mathrm{min}^{-1} \\
\text { heating rate }\end{array}$ & $\begin{array}{l}\text { From } 120^{\circ} \mathrm{C} \text { up to } 500^{\circ} \mathrm{C} \text {; } \\
\text { at } 5^{\circ} \mathrm{C} \cdot \mathrm{min}^{-1} \text { heating rate, } \\
\quad 3 \text { hours hold }\end{array}$ & $\begin{array}{l}\text { From } 500^{\circ} \mathrm{C} \text { down to } \\
\text { room temperature, at } \\
10^{\circ} \mathrm{C} \cdot \mathrm{min}^{-1} \text { cooling heat }\end{array}$ \\
\hline $\begin{array}{c}\mathrm{Al}(\mathrm{OH})_{3} \text { sintered at } \\
1500^{\circ}\end{array}$ & $\begin{array}{l}\text { From room } \\
\text { temperature up to } \\
800^{\circ} \mathrm{C}, 2^{\circ} \mathrm{C} \cdot \mathrm{min}^{-1} \\
\text { heating rate }\end{array}$ & $\begin{array}{c}\text { From } 800^{\circ} \mathrm{C} \text { up to } \\
1500^{\circ} \mathrm{C} ; \text { at } 5^{\circ} \mathrm{C} \cdot \mathrm{min}^{-1} \\
\text { heating rate, } 3 \text { hours hold }\end{array}$ & $\begin{array}{l}\text { From } 1500^{\circ} \mathrm{C} \text { down to } \\
\text { room temperature, at } \\
10^{\circ} \mathrm{C} \cdot \mathrm{min}^{-1} \text { cooling rate }\end{array}$ \\
\hline
\end{tabular}

Source: Author

The raw materials were homogenized Figure 12-h) in paddler mixer (IKA, Germany) at $100 \mathrm{rpm}$ for 5 minutes (Figure 13-a). Such low rotation and short mixing time were used to preserve the structure obtained after sintering of aluminum hydroxide [69]. The suspensions were dried overnight at $60{ }^{\circ} \mathrm{C}$ and then deagglomerated (Figure 12-i) to be uniaxially pressed at $40 \mathrm{MPa}$ (Figure 12-J) as prismatic bars $6 \times 20 \times 70 \mathrm{~mm}$, for bending testes, and as cylinders of $6 \times 10 \mathrm{~mm}$, for dilatometric analysis (Figure 13-b). Some of these bars were additionally compacted by isostatic pressing (CP360, USA) (Figure 12-k) at $100 \mathrm{MPa}$ for $5 \mathrm{~min}$.

Figure 13: Devices used in processing a) paddle-mixer b) metallic mold for uniaxial pressing c) polymeric mold for direct casting

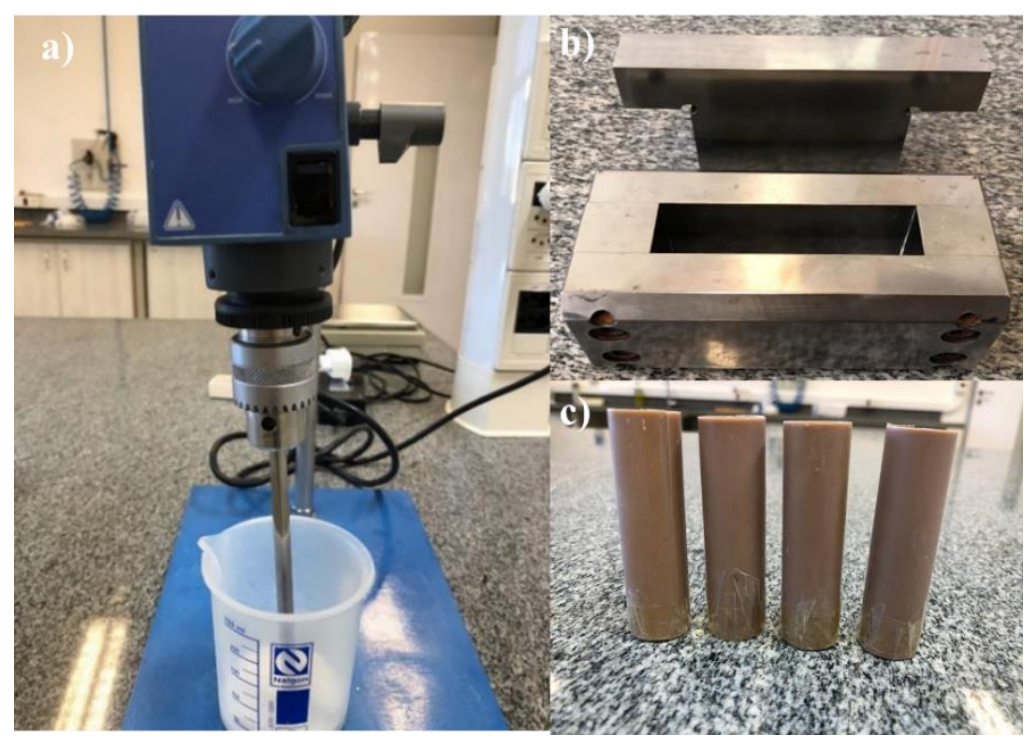

Source: Author

\subsection{Preparation of directly cast samples}

Samples were prepared as a mixture of pre-sintered aluminum hydroxide $\left(\alpha-\mathrm{Al}_{2} \mathrm{O}_{3}\right)$ 
(Figure 13-c), hydratable alumina (Alphabond 300, Almatis, USA) as a binder in the proportion of $20 \%$ volume of $\alpha-\mathrm{Al}_{2} \mathrm{O}_{3}$ and water or colloidal alumina as liquid phases (Figure 12-f and h). A poly(eyhylene glycol)-based electrosteric dispersant (FS20, Castment, BASF, Germany, $0.3 \mathrm{wt} \%$ dry-basis) and an antifoam agent (Tensiol, Lamberti, Italy, $0.05 \mathrm{wt} \%$ dry-basis) were added to the suspensions to, respectively, improve particle's homogenization and dispersion, and to prevent air bubbles entrapment. The powders were dry-mixed, gradually added to the water and homogenized (Figure 12-h) in a paddle mixer (PowerVisc, IKA, $100 \mathrm{rpm}, 5$ minutes). The amount of water used were previously determined (Table 2 ) to ensure suitable flowability for casting under vibration and enough strength for demolding. Similar conditions were employed in previous works of the research group [45,47].

Table 2: Composition of samples

\begin{tabular}{c|c|c|c|c}
\hline \multicolumn{2}{c|}{ Raw Materials } & \multirow{2}{*}{ Pressed } & \multicolumn{2}{c}{ Direct Cast } \\
\cline { 3 - 4 } $\begin{array}{c}\text { Solids } \\
\text { \%vol | \% wt }\end{array}$ & Previously sintered Al(OH) & $100.0 \mid 100.0$ & $13.5 \mid 27.8$ & $13 . .0 \mid 36.4$ \\
\hline $\begin{array}{c}\text { Liquid phases } \\
\text { \%vol | \% wt }\end{array}$ & Alphabond & - & $2.5 \mid 3.8$ & $2.6 \mid 5.0$ \\
\hline $\begin{array}{c}\text { Additives } \\
\%\end{array}$ & Colloidal Alumina & - & $84.0 \mid 68.4$ & - \\
\hline
\end{tabular}

Compositions were cast under vibration (Figure 12-1) in nonadherent polymeric cylindric molds of $15 \mathrm{~mm}$ diameter x $60 \mathrm{~mm}$ length (Figure 13-c).The molds were kept in closed flasks for $24 \mathrm{~h}$ at $60^{\circ} \mathrm{C}$ to maintain humidity close to $100 \%$ during cure. Afterward, samples were transferred to a circulating atmosphere (Venticell, MMM Group, Germany) for $24 \mathrm{~h}$ at $60^{\circ} \mathrm{C}$, demolded, and dried at $120^{\circ} \mathrm{C}$ for another $24 \mathrm{~h}$ to prevent risks of explosive spalling during the first heat-up [71] (Figure 12-m). 


\subsection{Thermal Treatment}

All compositions were obtained in triplicate and sintered according to the program presented in Table 3.

Table 3: Sintering programs

\begin{tabular}{|c|c|c|c|}
\hline Heating (Step 1) & Heating (Step 2) & $\begin{array}{c}\text { Treatment } \\
\text { Temperature }\end{array}$ & Cooling \\
\hline $\begin{array}{l}\text { From room } \\
\text { temperature up to } \\
800^{\circ} \mathrm{C}, 2^{\circ} \mathrm{C} \cdot \mathrm{min}^{-1} \\
\text { heating rate }\end{array}$ & $\begin{array}{c}\text { From } 800^{\circ} \mathrm{C} \text { up to } \\
\text { treatment temperature; at } \\
5^{\circ} \mathrm{C} \cdot \mathrm{min}^{-1} \text { heating rate, } 3 \\
\text { hours hold }\end{array}$ & $\begin{array}{l}1100^{\circ} \mathrm{C} \\
1300^{\circ} \mathrm{C} \\
1500^{\circ} \mathrm{C} \\
1600^{\circ} \mathrm{C}\end{array}$ & $\begin{array}{c}\text { From treatment } \\
\text { temperature down to } \\
\text { room temperature, at } \\
10^{\circ} \mathrm{C} \cdot \mathrm{min}^{-1} \text { cooling } \\
\text { heat }\end{array}$ \\
\hline
\end{tabular}

Source: Author

\subsection{Test Methods}

Samples' dimensions and mass were measured before (Figure 13-N) and after (Figure 13O) each thermal treatment to calculate their linear shrinkage (LS, \%), apparent density (AD, $\left.\mathrm{g} / \mathrm{cm}^{3}\right)$, relative density $(\mathrm{RD}, \%)$ and total porosity (TP, \%) using the following equations:

$$
\begin{gathered}
\operatorname{LVS}(\%)=100 \% \times\left[\frac{\mathrm{L}_{0}-\mathrm{L}_{\mathrm{F}}}{\mathrm{L}_{0}}\right] \\
\mathrm{AD}(\%)_{\text {Prismatic }}=\frac{\mathrm{M}_{\mathrm{i}}}{\mathrm{L}_{\mathrm{i}} \times \mathrm{W}_{\mathrm{i}} \times \mathrm{T}_{\mathrm{i}}} \\
\mathrm{AD}(\%)_{\text {Cylindrical }}=\frac{\mathrm{M}_{\mathrm{i}}}{\frac{\pi D^{2}}{4} \times L} \\
\mathrm{RD}(\%)=100 \% \times\left[\frac{\mathrm{AD}_{\mathrm{i}}}{\rho_{\mathrm{s}}}\right] \\
\mathrm{TP}(\%)=100-\mathrm{RD}
\end{gathered}
$$

where $\mathrm{M}, \mathrm{T}, \mathrm{W}, \mathrm{L}, \mathrm{D}, \rho_{\mathrm{S}}$ are, respectively sample's mass $(\mathrm{g})$, thickness $(\mathrm{cm})$, width $(\mathrm{cm})$, length $(\mathrm{cm}), \mathrm{D}$ (diameter) and solid density $\left(\mathrm{g} . \mathrm{cm}^{-3}\right.$, measured by Helium pycnometer technique in equivalent samples and crushed and sieved up to $\left.\mathrm{D}_{\text {Part }}<100 \mu \mathrm{m}\right)$. 
The thermal linear variation on green dried and sintering samples $\left(1600^{\circ} \mathrm{C}\right)$ was continuously measured in a contact dilatometer (DIL402C, Netzsch, Germany, $5^{\circ} \mathrm{C} / \mathrm{min}$ heating rate, up to $\left.1600^{\circ} \mathrm{C}\right)$.

Flexural Young's modulus (E, GPa) of the fired samples was measured using impulse excitation of vibration technique according to ASTM E 1876-01 standard ("Standard Test Method for Dynamic Young's Modulus, Shear Modulus, and Poisson's Ratio by Impulse Excitation of Vibration", Sonelastic equipment, ATCP, Brazil) [72]. The equipment identifies the fundamental resonance frequencies to determine $\mathrm{E}$ by detecting the acoustic signals generated when a mechanical actuator impact the specimen. After, the relative value were calculated as the ratio between experimental $\left(E_{\exp }\right)$ and theoretical $\left(E_{\text {dense }}\right)$, the values attained in this work and the correspondent ones for fully dense compositions (pollycristalline alumina).

$$
E_{\text {relative }}=\frac{E_{\text {exp }}}{E_{\text {dense }}}
$$

Flexural modulus of rupture (MOR, MPa) of the specimens was determined by 3-point bending test, performed in a universal testing machine (Model WDW-30E; Time Group Inc., China) equipped with a $5-\mathrm{kN}$ load cell and at a crosshead speed of $0,5 \mathrm{~mm} / \mathrm{min}$ according to ISO 6872 ("Flexural Strenght Testing of Dental Ceramics")[73], equation 10 and 11:

$$
\begin{gathered}
\sigma_{\text {prismatic }}=\frac{3 \times \mathrm{P} \times \mathrm{l}}{2 \times \mathrm{w} \times \mathrm{t}^{2}} \\
\sigma_{\text {cilyndrical }}=\frac{8 \times \mathrm{P} \times \mathrm{l}}{\pi \times \mathrm{D}^{3}}
\end{gathered}
$$

where $P$ is the breaking load in Newtons; $l(\mathrm{~mm})$ is the test span (center-to-center distance between support rollers); $w(\mathrm{~mm})$ is the width of the specimen; $\mathrm{t}(\mathrm{mm})$ is the thickness of the specimen. For TP, E, $\sigma_{\mathrm{r}}$, LS measurements at least 3 samples were tested for each condition.

The fractures cross-sections of the samples were examined by field emission gun scanning electron microscopy (FEG-SEM, FEI Inspect F50, Netherlands).

Pore size distribution of the sintered samples was obtained by mercury intrusion porosimetry (PoreMaster 33, Quantochrome Instruments, USA; mercury surface tension equal to $0.480 \mathrm{~N} \cdot \mathrm{m}^{-1} ; 130^{\circ}$ contact angle and pressure applied ranging between $0.0014-210 \mathrm{MPa}$ ). In this technique, the intrusion of mercury is forced by increments of pressure, filling large pores first and as the pressure increase, smaller pores are filled. Washburn model relates the applied 
pressure to pore diameter using physical properties of mercury such as contact angle between it and the material.

Thermal conductivity measurement was performed from $600^{\circ} \mathrm{C}$ up to $1400^{\circ} \mathrm{C}$ in a laser flash apparatus (Netszch, LFA427, Germany) with samples previously sintered (at $1500^{\circ} \mathrm{C}$ and $1600^{\circ} \mathrm{C}$ ) and sliced as cylinders of $6 \mathrm{~mm}$ diameter by $1 \mathrm{~mm}$ length. In this method, the lower surface of a parallel sample is heated by a short pulse of $\mathrm{CO}_{2}$,laser, then the temperature change on the upper surface of sample is measured with an infrared detector, which allow to calculate thermal conductivity. 


\section{RESULTS AND DISCUSSION}

\subsection{Raw- Materials Characterization}

The raw materials used for samples preparation were characterized (Table 4). Comparing density, specific surface area and particle size (Table 4) of as-received and sintered $\mathrm{Al}(\mathrm{OH})_{3}$, an increase of density was observed due to the transformation of the crystalline phase of aluminum hydroxide, gibbsite, into $\alpha$-alumina when sintered at $1500^{\circ} \mathrm{C} / 3 \mathrm{~h}$. The particles' sizes in both cases are similar, however the sintered particles presented a much lower specific surface area because the surface mesopores disappear during sintering and coalesce into larger ones.

Table 4: Characterization of Raw Materials

\begin{tabular}{|c|c|c|c|c|}
\hline Characteristics & $\mathbf{A l}(\mathbf{O H})_{3}(\mathbf{A H})$ & $\begin{array}{c}\text { Sintered Al }(\mathrm{OH})_{3} \\
(\mathrm{SAH})\end{array}$ & $\begin{array}{c}\text { Hydratable } \\
\text { alumina (HA) }\end{array}$ & $\begin{array}{c}\text { Colloidal } \\
\text { Alumina (CA) }\end{array}$ \\
\hline Production Method & Bayer Process & $\begin{array}{l}\text { Sintering at } \\
1500^{\circ} \mathrm{C} / 3 \mathrm{~h}\end{array}$ & $\begin{array}{c}\text { Flash-calcination } \\
\text { of } \mathrm{Al}(\mathrm{OH})_{3}\end{array}$ & - \\
\hline Crystalline Phases & $\begin{array}{l}\text { Gibbsite }(\alpha- \\
\left.\operatorname{Al}(\mathrm{OH})_{3}\right)\end{array}$ & $\alpha-\mathrm{Al}_{2} \mathrm{O}_{3}$ & $\begin{array}{l}\text { Amorphous }(\rho- \\
\left.\qquad \mathrm{Al}_{2} \mathrm{O}_{3}\right)\end{array}$ & $\begin{array}{c}\text { Pseudo-bohemite } \\
\left(\mathrm{Al}_{2} \mathrm{O}_{3} \cdot \mathrm{H}_{2} \mathrm{O}\right)\end{array}$ \\
\hline $\begin{array}{c}\text { Chemical } \\
\text { composition }(\mathrm{wt} \%)\end{array}$ & $\begin{array}{c}\mathrm{Al}(\mathrm{OH})_{3}: 99,7 \\
\mathrm{Na}_{2} \mathrm{O}: 0.2 \\
\mathrm{Fe}_{2} \mathrm{O}_{3}: 0.07 ; \mathrm{SiO}_{2} \\
0.03\end{array}$ & - & $\begin{array}{c}\mathrm{Al}_{2} \mathrm{O}_{3}: 99.4 \\
\mathrm{Na}_{2} \mathrm{O}: 0.5 ; \\
\mathrm{Fe}_{2} \mathrm{O}_{3}: 0.02 ; \mathrm{SiO}_{2}: \\
0.03 ; \mathrm{CaO}: 0.02 \\
\mathrm{MgO}: 0.07\end{array}$ & $\begin{array}{c}\mathrm{Al}_{2} \mathrm{O}_{3}: 20.0 \\
\mathrm{AlO}(\mathrm{OH}) 23.5 \\
\mathrm{H}_{2} 0: 56.5\end{array}$ \\
\hline Solid density $\left(\mathrm{g} / \mathrm{cm}^{3}\right)$ & 2.42 & 4.17 & 2.72 & - \\
\hline $\begin{array}{l}\text { Specific Surface Area } \\
\qquad\left(\mathrm{m}^{2} / \mathrm{g}\right)\end{array}$ & 5.8 & 1.4 & 95 & 100 \\
\hline $\begin{array}{c}\text { Particle Size }\left(\mathrm{D}_{50} / \mathrm{D}_{90}\right. \\
\mu \mathrm{m})\end{array}$ & $0.9 / 1.2$ & $0.89 / 1.19$ & $7.6 / 31$ & $0.6-0.9$ \\
\hline
\end{tabular}

Source: Author

Two binders were used in this work: hydratable alumina and colloidal alumina. Hydratable alumina is generally obtained by flash-calcination, having as product rho-alumina (Table 4). This phase can re-hydroxilate, transforming, initially, into alumina gel and further crystalizes and form phases of aluminum hydroxide as bohemite and bayerite [74]. Due to this formation of aluminate hydrates, HA promotes initial strength to the compound [75]. However, during initial heating above $300^{\circ} \mathrm{C}$, bohemite begin to collapse and shrink due to dihydroxylation leading to loss of strength and rigidity [76].

In recent years, the use of colloidal suspensions increased in refractory industry because can improve the refractory's bonding and densification at lower temperatures. Their setting mechanism occurs by means of gelation reactions triggered by drying or additives such as $\mathrm{MgO}$. During the gelation, suspensions' concentration increase, forcing particles to approach each 
other, forming a gel-phase. When combined with other refractory particles, the colloidal ones are linked together in branched chains, leading to the solidification of the sol into a threedimensional network. As the coalescence of colloidal particles occurs at the contact points amongst the micrometric ones, the whole structure becomes stiffer and rigid [77].

\subsection{Preliminary tests with as-received, calcined and sintered aluminum hydroxide}

Previous tests were conducted with as-received $\mathrm{Al}(\mathrm{OH})_{3}$ (Figure 15-a) because, in this case, it could be possible to obtain a porous material, maintaining the structural integrity with no extra energy consumption involved in the material processing. Nonetheless, after pressing and submitting to heat treatment at $1500^{\circ} \mathrm{C}$ the samples presented severe cracks (Figure $14 \mathrm{a}$ ) and lamination.

Cracks were generated during the heating process as a result of the releasing of hydroxyl groups $(\mathrm{OH})$ present in its crystalline structure, forming water vapor (Eq. 13) which are responsible for pressurizing the structure internally [78]. Studies showed that, at this stage, approximately $34 \mathrm{wt} \%$ mass loss can be observed at $208-370^{\circ} \mathrm{C}$, followed by density increase $[17,63,79,80]$.

$$
2 \mathrm{Al}(\mathrm{OH})_{3} \rightarrow 3 \mathrm{H}_{2} \mathrm{O}+\mathrm{Al}_{2} \mathrm{O}_{3}
$$

Figure 14: Pressed samples comprised by a) as-received aluminum hydroxide and b) aluminum hydroxide previously calcined at $500^{\circ} \mathrm{C}$. Both samples were sintered at $1500^{\circ} \mathrm{C} / 3 \mathrm{~h}$.

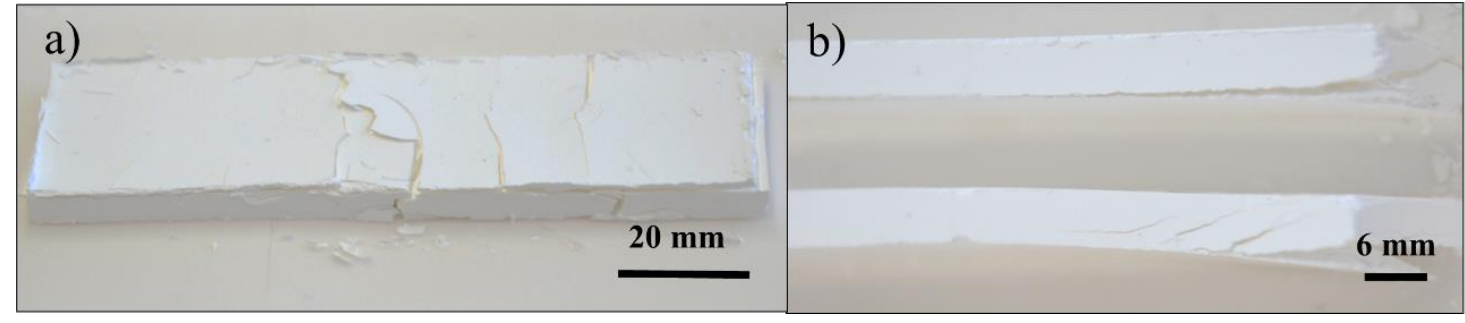

Source: Author

For this reason, the $\mathrm{Al}(\mathrm{OH})_{3}$ particles were calcined at $500^{\circ} \mathrm{C}$ before samples preparation. Despite this, lamination occurred due to contraction that $\mathrm{Al}(\mathrm{OH})_{3}$ experiences after dehydroxylation (Figure $14 \mathrm{~b}$ ), leading to a higher density. Studies demonstrated that the specimens undergo approximately $60 \%$ of volume contraction, due to phase changes until reaching the stable phase of alumina [68]. At $500^{\circ} \mathrm{C}$ the transition alumina $\left(\chi-\mathrm{Al}_{2} \mathrm{O}_{3}\right)$ obtained is not fully stable, had low crystallinity and a large concentration of defects and can transform into other phases easily (into $\mathrm{K}-\mathrm{Al}_{2} \mathrm{O}_{3}$ at $900^{\circ} \mathrm{C}$, and at $1100^{\circ} \mathrm{C} \alpha-\mathrm{Al}_{2} \mathrm{O}_{3}$ ). 
Another study of the author's research group (SiMMaC) directly cast aqueous suspensions of $\mathrm{Al}_{2} \mathrm{O}_{3}-\mathrm{Al}(\mathrm{OH})_{3}$ mixtures and attained different results [45]. These samples maintained integrity because of three effects 1 ). Such method promoted more spaced particles so that water can leave the structure by inter-particle pores; 2) the maximum amount of $\mathrm{Al}(\mathrm{OH})_{3}$ used were smaller (70 vol\%) compared to this work (100 vol\%); 3) the binder acted strengthening the structure, allowing its recomposition at high-temperatures.

The use of very low heating rates $\left(0.5^{\circ} \mathrm{C} \cdot \mathrm{min}^{-1}\right)$ was also tested as a way to easy the water release, decreasing the pressure inside the specimen. In spite of this, such change did not help because the material is very compact and have small pores. Thus the water vapor passed through crystalline structure and promote cracks even in that condition. Besides, lamination still ocurrs because is a physical change that do not depend on heating rates. Gan (2009) studies showed that the use of higher heating rates increase the transformation temperature of the transition aluminas, by revealed similarity in phase changes [65]. On the other hand, the possibility of produce smaller samples were discarded because the application as insulators require large pieces. Moreover, even small specimens presented these mentioned behaviors because the material is very compacted.

Thereby, it was necessary to previously sinter $\mathrm{Al}(\mathrm{OH})_{3}$ at $1500^{\circ} \mathrm{C}$ to overcome the difficulties faced during previous heat treatment. At this temperature, $\alpha-\mathrm{Al}_{2} \mathrm{O}_{3}$ filaments are completely dense and surrounded by continuous elongated macroporous (Figure 15-b). This microstructure is obtained because the initial coordination number of a powder compact can be alter by mass transport, so in the first stage of sintering, pores disappear to form dense regions such as agglomerates or domains, at the same time the size and coordination number of interdomain pores increase. During the later stages, grain growth and rearrangement decreases the coordination number of remaining pores as well as their size, resulting in disappearance of interdomain pores $[60,81,82]$. 
Figure 15: SEM images of a) as-received $(\mathrm{AH})$ and b) $\mathrm{Al}(\mathrm{OH})_{3}$ sintered at $1500^{\circ} \mathrm{C}(\mathrm{SAH})$
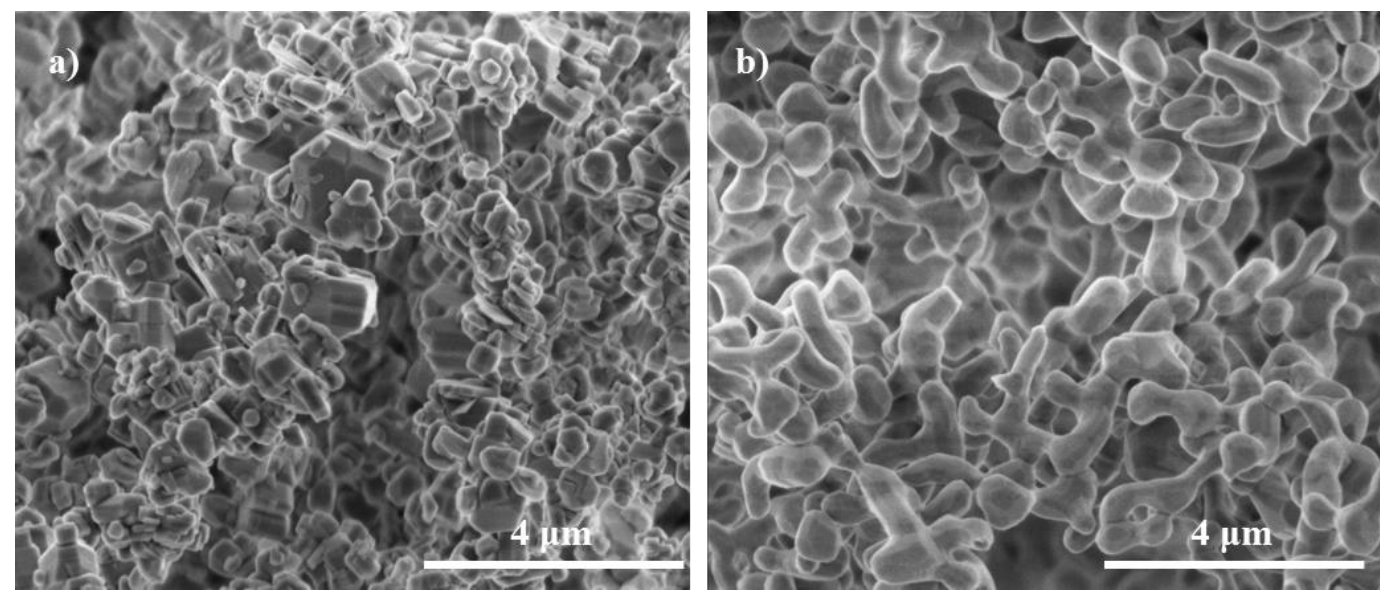

Source: Author

All samples prepared with previously sintered $\mathrm{Al}(\mathrm{OH})_{3}$ survived after thermal treatment with no signs of delamination or cracks. Due to this, in the next sections, all tests were conducted using such raw material.

\subsection{Preliminary test of the direct cast with water and colloidal alumina}

Green samples prepared with plain water as liquid medium (Figure 16-a) and hydratable alumina as a single binder presented low mechanical resistance when handled in comparison to those cast with colloidal alumina (Figure 16). Colloidal alumina which is a stable suspension of alumina nanoparticles can be a suitable a substitute to water because it acts as a binder as well as a liquid phase. After drying, it forms a high permeable and porous structure that provides a faster and safer water dry-out step $[77,83]$. Besides, the green mechanical strength after curing $\left(60^{\circ} \mathrm{C}\right)$ provided is similar to calcium aluminate cement and superior to hydratable alumina $[77,83]$.

Then, based on these advantages, the direct cast samples evaluate in this work were prepared with colloidal alumina as liquid medium (Figure 16-b) and hydratable alumina as hydraulic binder to improve even further the strength of green samples. 
Figure 16: Samples directly cast with a) water and hydratable alumina and with b) colloidal alumina and hydratable alumina after demolding and drying

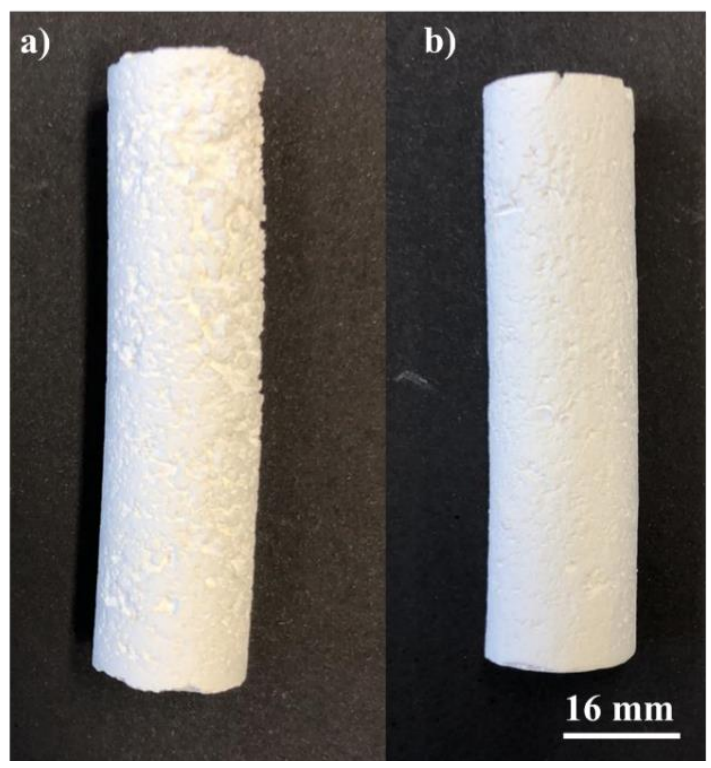

Source: Author

\subsection{Test of processing methods}

Direct cast is an interesting processing route to produce porous ceramic because it maintains a significant distance among particles, which contributes to generate high levels of porosity [45]. On the other hand, although isostatic and uniaxial pressing compact the particles, and consequently, decrease the porosity level, they also allow a better dimensional control. Besides, there are applications of structural insulators with TP ranging between $10-50 \%$ that could be prepared using these methods.

Schematic representation shows the transformation of $\mathrm{Al}(\mathrm{OH})_{3}$ into transition alumina (Figure 17-b), followed by the obtainment of coral-like structure (Figure 17-c) and the processing routes of this work. Firstly, $\mathrm{Al}(\mathrm{OH})_{3}$ (Figure 17-a) undergone for transitions alumina phases (Figure 17-a), until attained its most stable phase $\left(\alpha-\mathrm{Al}_{2} \mathrm{O}_{3}\right.$, Figure 17-c) by sintering the powder at $1500^{\circ} \mathrm{C}$. 
Figure 17: Schematic representation of the production and processing of coral-like structures.

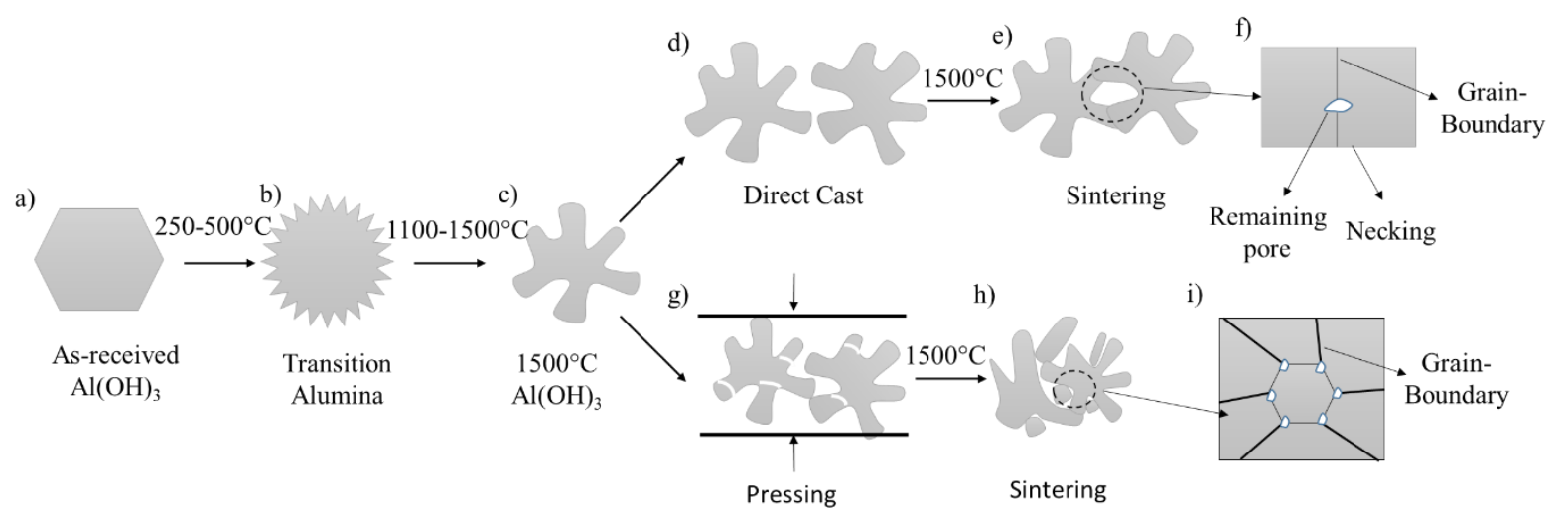

Source: Author

Following, part of the material was direct cast (Figure 17-d) and part was pressed (Figure 17 -g). Directly cast green samples showed the highest value of TP $(74,36 \%)$ in comparison to isostatic and uniaxial pressed (56,31\% and 61,5\%, respectively). The difference between pressing methods is because the magnitude of the applied pressure in isostatic is higher than in uniaxial, resulting in greater particle packing and lower porosity levels. Such effect can be seen on SEM images of green samples on Figure 21.

Figure 18: Total Porosity obtained for direct cast, uniaxial and isostatic pressing methods

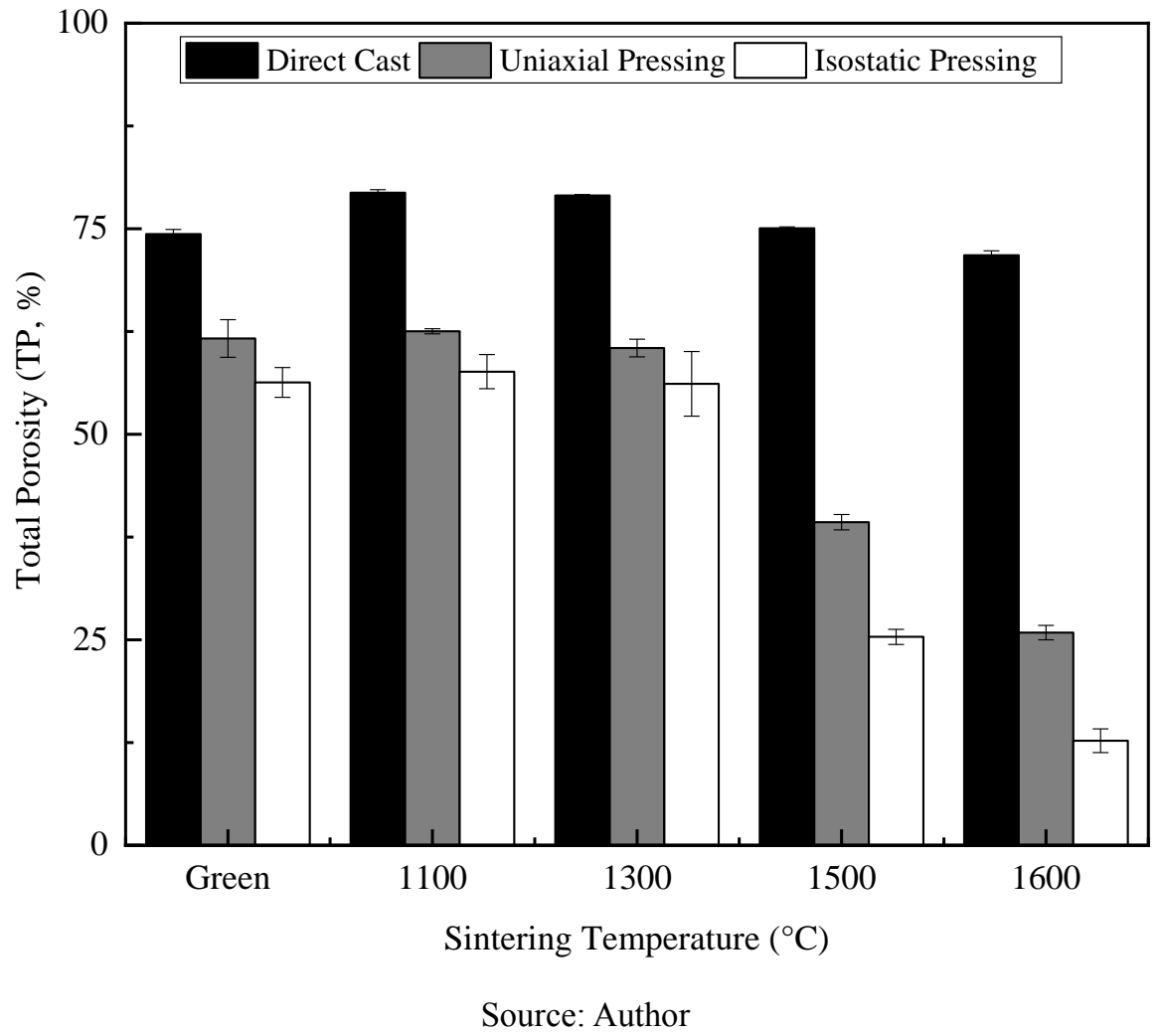


Lower levels of TP (Figure 18) favored an increase in flexural strength and rigidity (Figure 20). Elastic modulus was affected by interatomic bonds, being its magnitude a measure of the resistance to separation of adjacent atoms. Thus, the presence of pores decreases the material rigidity because the particles had less contact points in these regions. The flexural modulus of rupture is also influenced by pores, because they act as stress concentrators and reduce the cross-sectional area where a load is applied.

Thermal treatments conducted at $1100^{\circ} \mathrm{C}$ and $1300^{\circ} \mathrm{C}$ were not sufficient to promote a significant reduction of total porosity (Figure 18) for all methods evaluated. The thermal energy at this temperature range was not enough to trigger the long-range transport mechanism that promotes densification by bulk diffusion (Figure 21). Nevertheless, surface diffusion is a mechanism that occurs at the contact point amongst particles and requires much less energy. Due to this, the formation of more effective bonds (necking) occurred at such temperature range (Figure 21), increasing mechanical properties. Therefore, a significant increase in the mechanical properties (Figure 20) was observed for samples fired at $1300^{\circ} \mathrm{C}$.

In pressed samples, a compacting tension was applied, reducing the space amongst particles and generating some broken filaments (Figure 19). The smaller parts originated from such breakage, filled empty spaces leading to a more effective packing. For this reason, at $1500^{\circ} \mathrm{C}$ and $1600^{\circ} \mathrm{C}$, higher levels of densification occurred between the particles (Figure 21) due to mass transport by volume diffusion and grain boundary, resulting in porosity loss and significant gain in mechanical properties. In isostatic pressing, samples were initially denser than those uniaxially pressed, therefore, at $1500^{\circ} \mathrm{C}$ the sintering process was more intense and the microstructure showed a change in the particle formats. In uniaxial pressing, the same effects were observed more significantly at $1600^{\circ} \mathrm{C}$. Despite this, samples had significant fraction of residual pores at $1600^{\circ} \mathrm{C}$ (Figure 21). The difficulty for close them was imposed by the geometry of the coral-like particles, which are irregular with many cavities, resulting in pores with more sides than the critical number. 
Figure 19: SEM images of filaments broken of pressed green samples a) uniaxial b) isostatic

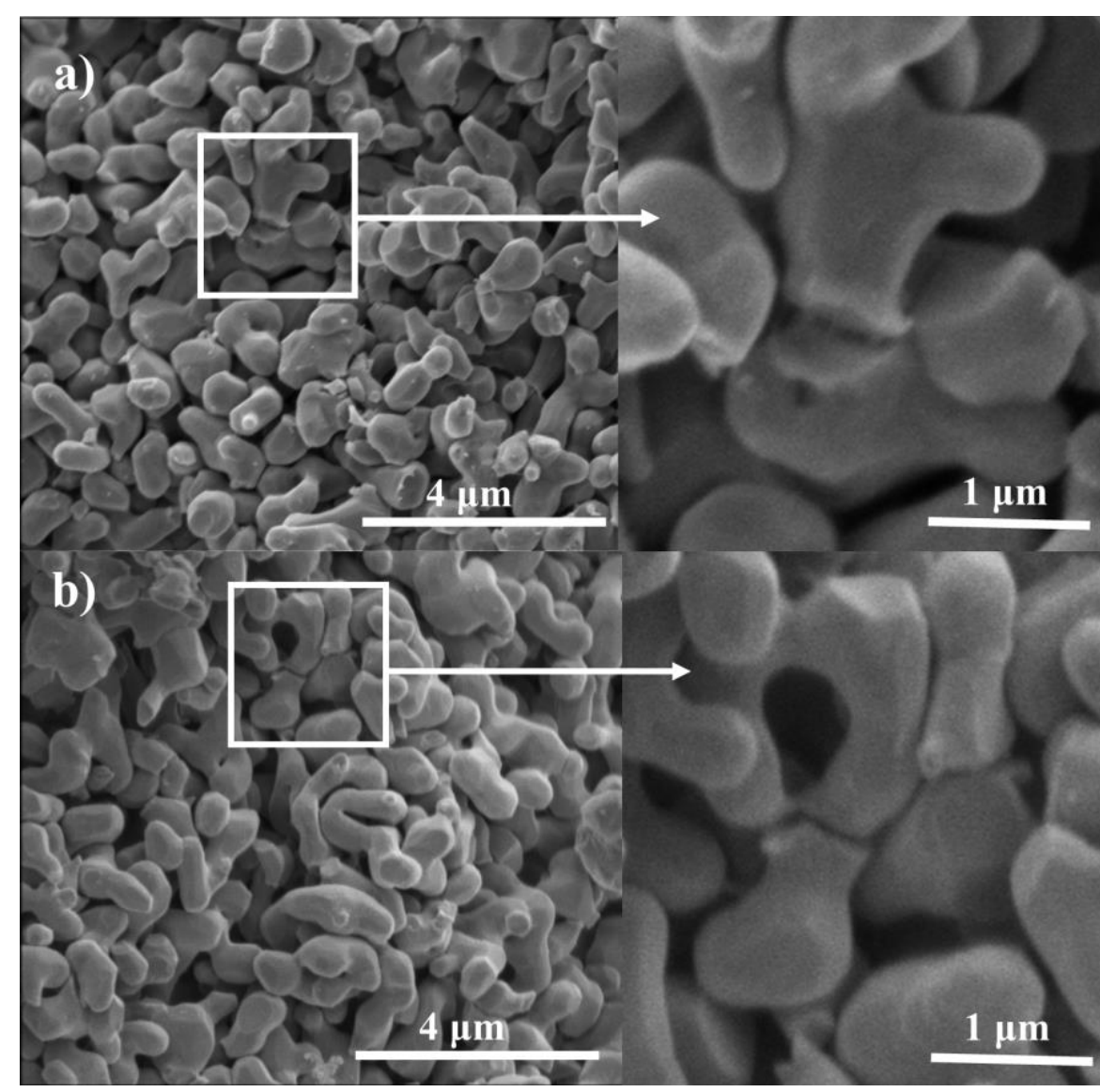

Source: Author

Direct cast samples showed the highest levels of porosity (Figure 18) for all temperatures studied. Such processing route (Figure 17-d) maintained most of the initial distance amongst the particles (Figure 21), hindering matter transport, which is essential for the sintering process. Thus, the main mechanism that occurred was surface diffusion, which created elongated necks between the contact points amongst the particles (Figure 17), increasing the resistance of the material, without promoting significant densification.

At $1500^{\circ} \mathrm{C}$, particles from hydratable and colloidal alumina were absorbed by the corallike, resulting in their thickening (Figure 21). In this case, the densification of the structure was hindered, because even at high-temperatures the intra-particles pores were not significantly affected due to the distance among them. Thus, the TP levels remained high and mechanical properties had a less intense increase when compared to pressed samples. Nevertheless, these values were sufficient to attain the properties required to thermal insulator application (1 MPa in flexural modulus of rupture, $\mathrm{TP}>40 \%$ ). 
Figure 20: Mechanical Properties a) Flexural Elastic Modulus b) Flexural Modulus of Rupture c) Linear Variation After Sintering
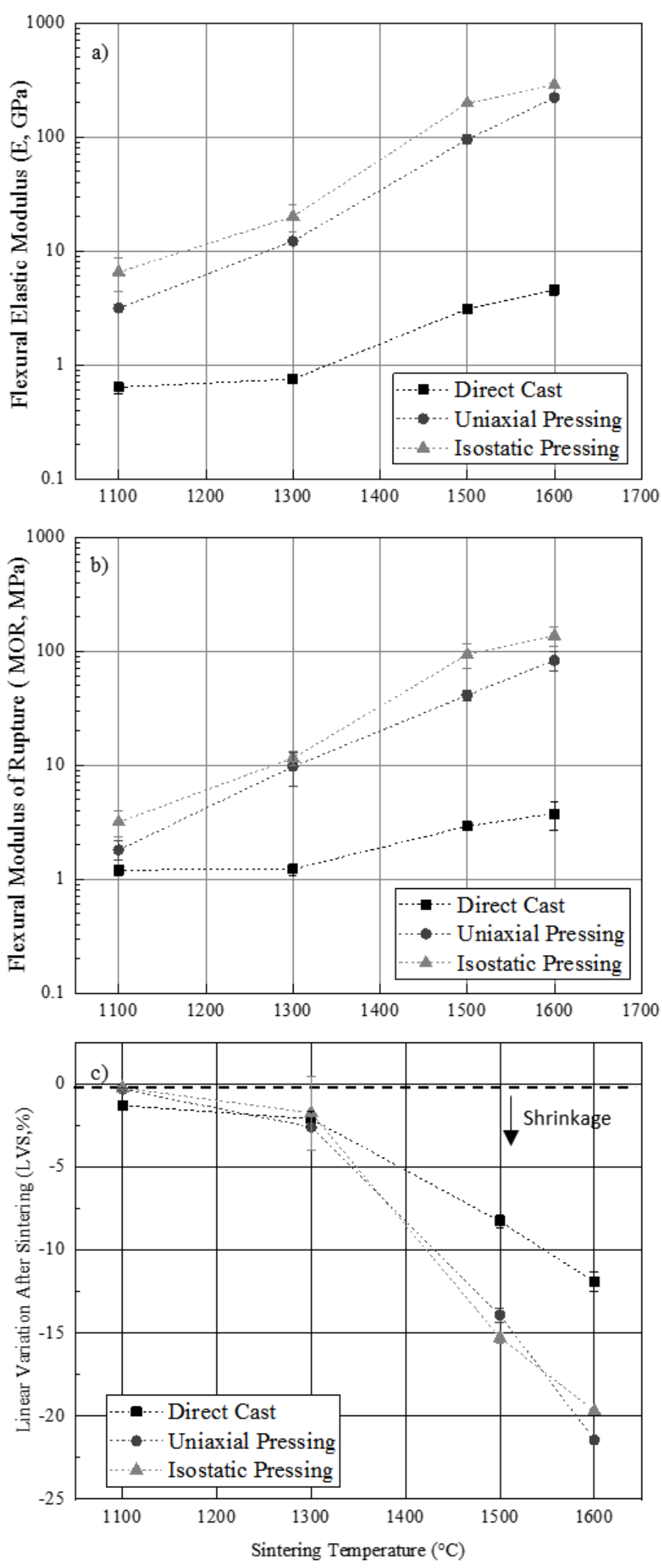

Source: Author 
Figure 21:SEM Image of fracture cross-sections of green-dried and sintered samples $\left(1100^{\circ} \mathrm{C}, 1^{\circ 00}{ }^{\circ} \mathrm{C}\right.$, $1500^{\circ} \mathrm{C}$ and $1600^{\circ} \mathrm{C}$ ) prepared using different compacting methods

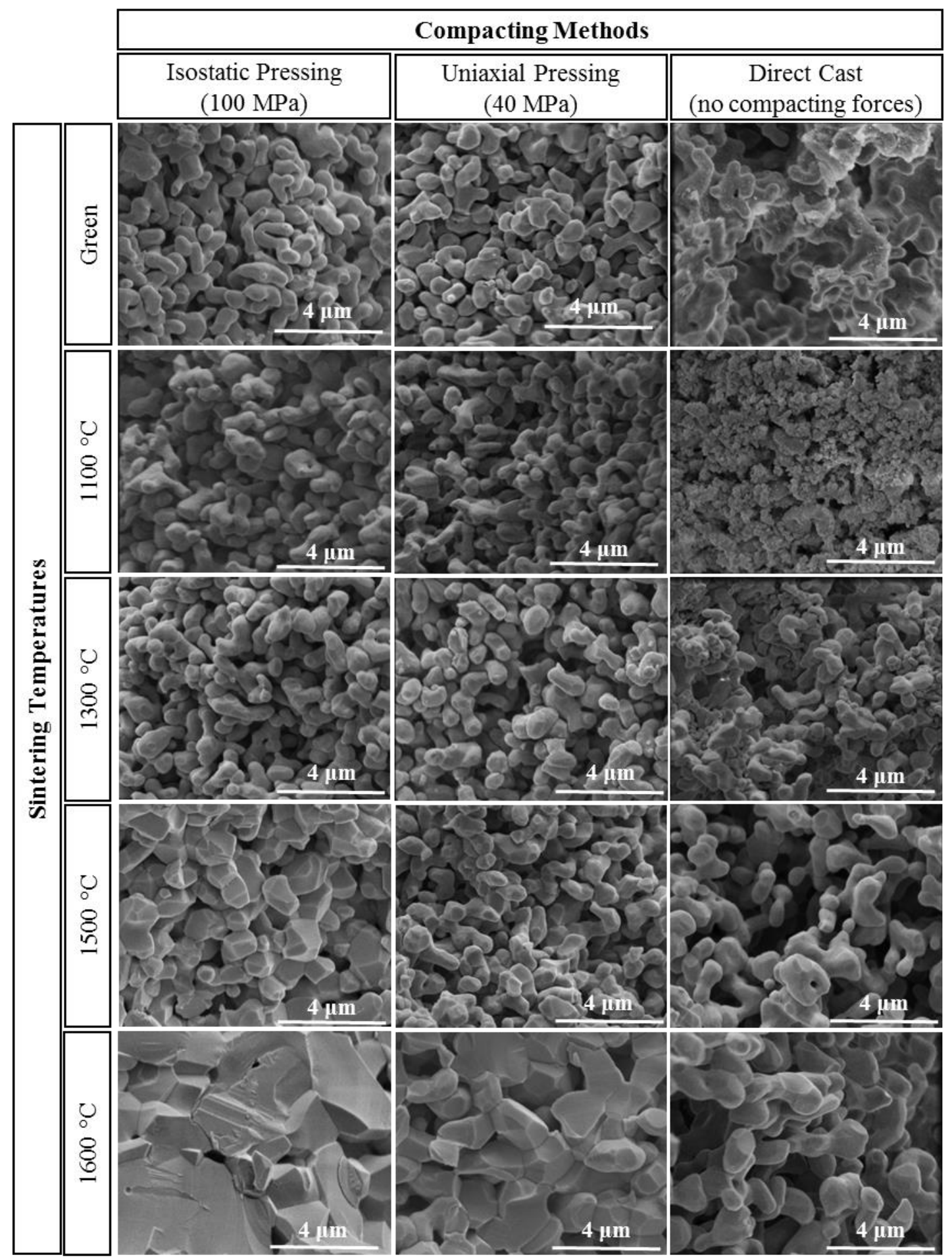

Source: Author 
Due to this more pronounced densification, there was a large shrinkage (Figure 20-c) in the isostatic $(21,43 \%)$ and uniaxial $(19,68 \%)$ pressed samples whereas the directly cast $(11,92 \%)$ ones maintained most of their dimensional stability even at high temperatures as a consequence of the lack densification. The first shrinkage event (Figure 22) observed for direct cast samples at $1100^{\circ} \mathrm{C}$ may be caused by the decomposition and sintering of the transition aluminas present in the sample (Figure 21); the second one occurred at $1400^{\circ} \mathrm{C}$ and was related to the densification process. The pressed samples presented similar behavior, showing the beginning of a contraction above $1300^{\circ} \mathrm{C}$.

Figure 22: a) Thermal Linear Variation b) Thermal Linear Variation Rate for direct cast and pressed
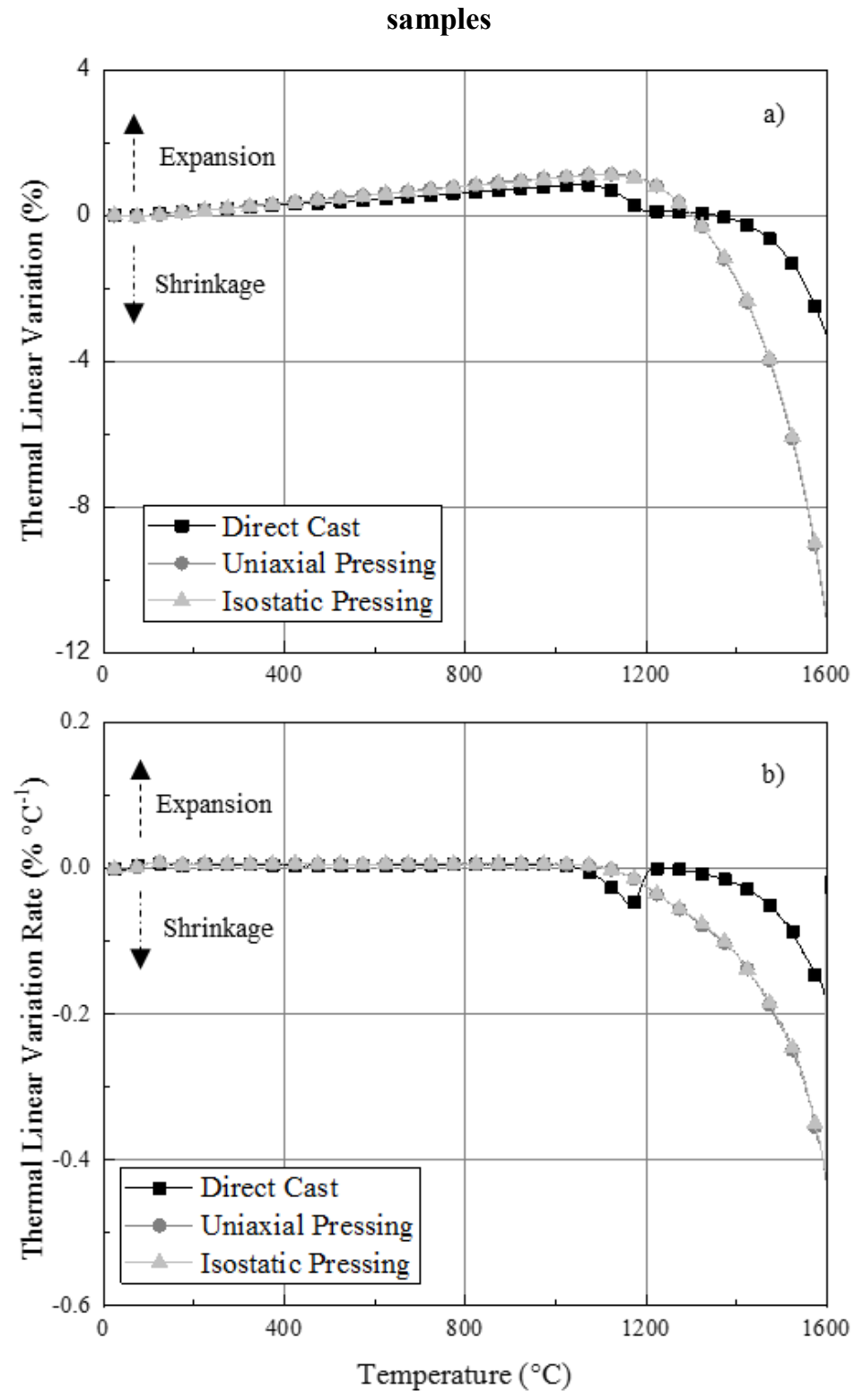

Source: Author 
An important analysis is the impact of the porosity in mechanical behavior of a porous material (Figure 23). The elastic modulus is mainly affected by volumetric fraction of pores $\left(\varnothing_{\text {pores }}\right)$ and the effectiveness of the bonding amongst particles. If such connections are effective and do not present cracks or other defects, the elastic modulus of porous structures can be expressed by Eq. 14 and represented by a line on the graph where relative elastic modulus equals relative density $(\mathrm{RE}=\mathrm{RD})$. However, in most cases, this not occurs and $\mathrm{E}$ varies in a non-linear way with the $\varnothing_{\text {pore }}$

$$
E_{\text {porous }}=E_{\text {dense }} \times\left(1-\emptyset_{\text {pores }}\right)
$$

The theoretical elastic modulus value used for $\mathrm{Al}_{2} \mathrm{O}_{3}(390 \mathrm{MPa})$ was obtained by Deng et al (2001), who prepared samples by cold pressing and then sintered them in a furnace with air atmosphere at $1350^{\circ} \mathrm{C}$ [68]. The relative density were calculated according to Eq. 8 and relative Young's modulus by Eq. 10 .

Figure 23: Comparison with other processing methods

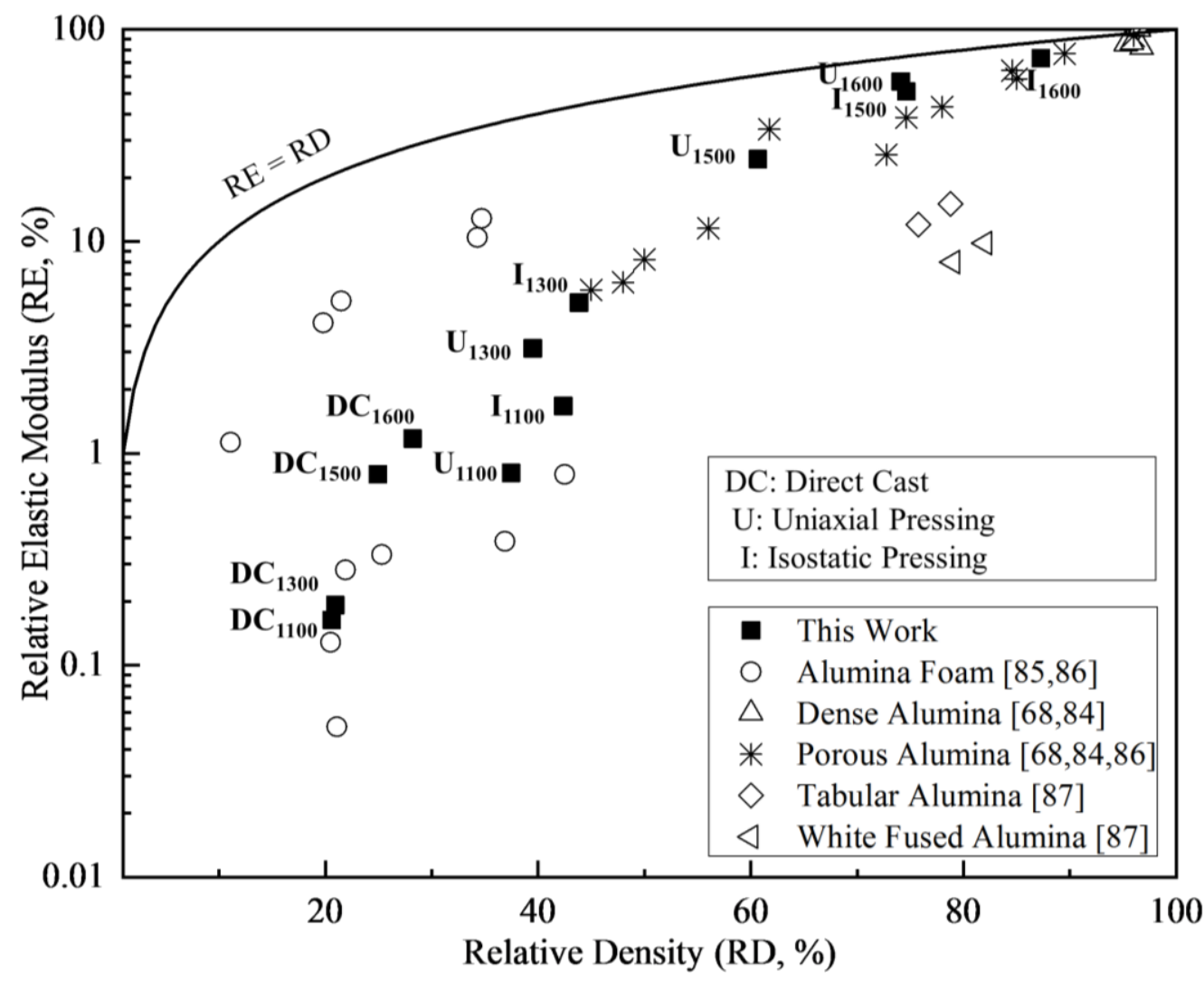

Source: Author 
The results of the present study were compared with dense [68,84], foamed $[85,86]$, porous $[68,84,86]$, tabular alumina [87] and white fused alumina [87] . Direct cast samples presented similar results to foamed alumina, whereas, pressed ones resulted in intermediate values, and $\mathrm{U}_{1500}$ and $\mathrm{I}_{1600}$ had greater elastic modulus for the same relative density when compared with porous alumina obtained from other methods.

Based on the results attained, using hindered densification as a mechanism for obtaining porous ceramics showed promising results for porosity and mechanical properties. However, the physical properties of sintered samples need to be evaluated regarding their use as thermal insulator.

\subsection{Physical Properties of Sintered Samples}

Thermal Linear Variation was evaluated for samples previous sintered at $1600^{\circ} \mathrm{C} / 3 \mathrm{~h}$ (Figure 24 a) to verify if the densification process was completed. Although the samples were stable up to $1200^{\circ} \mathrm{C}$, they presented significant signs of further densification above such temperature. For this reason, the Linear Expansion Coefficient ( $\alpha$, Figure 24-b), was calculated from $300^{\circ} \mathrm{C}$ up to $1200^{\circ} \mathrm{C}$ in and the average result is presented in Table 5. Figure 24 - a shows how $\alpha$ were calculated.

Table 5: Average Linear Expansion Coefficient Results $\left(300^{\circ} \mathrm{C}-1200^{\circ} \mathrm{C}\right)$

\begin{tabular}{ccccc}
\hline & Direct Cast & Uniaxial Pressing & Isostatic Pressing & Dense alumina [88] \\
\hline $\begin{array}{c}\text { Linear Expansion } \\
\text { Coefficient }\left(\boldsymbol{\alpha}, \mathbf{~ 1 0}^{-6}{ }^{\circ} \mathbf{C}^{-1}\right)\end{array}$ & 5.7 & 5.9 & 6.0 & 8.3 \\
Standard Deviation & 0.3 & 0.3 & 0.4 & - \\
\hline & \multicolumn{5}{c}{ Source: Author }
\end{tabular}

The values presented for the three processes are significantly smaller than the theoretical for alumina at $1200^{\circ} \mathrm{C}$. Such result presents an important technological implication regarding these materials' thermal shock resistance. The thermal tension generated during a certain temperature variation $\left(\Delta \mathrm{T},{ }^{\circ} \mathrm{C}\right)$ is directly proportional to $\alpha$ as evidenced by Equation 15 .

$$
\sigma_{\text {thermal }}=E \times \alpha \times \Delta T
$$

where $\mathrm{E}$ is elastic modulus $(\mathrm{Pa}), \alpha$ is linear expansion coefficient $\left(1 /{ }^{\circ} \mathrm{C}\right)$ and $\Delta \mathrm{T}$ is a temperature gradient $\left({ }^{\circ} \mathrm{C}\right)$. Thus, the lower the $\alpha$, the more resistant to thermal shock the material, because the thermal tension would be lower as well.

Considering thermal variation of $100^{\circ} \mathrm{C}$, the calculus of thermal tension for a dense material with $390 \mathrm{GPa}$ of elastic modulus and $300 \mathrm{MPa}$ of rupture tension is: 


$$
\sigma_{\text {thermal }}=390 \cdot 10^{9} \mathrm{~Pa} \cdot 8.3 \cdot 10^{-6}{ }^{\circ} \mathrm{C}^{-1} \cdot 100^{\circ} \mathrm{C}=323.7 \mathrm{MPa}
$$

The value for a porous material with $4 \mathrm{GPa}$ of elastic modulus and $4 \mathrm{MPa}$ of rupture tension is:

$$
\sigma_{\text {thermal }}=4 \cdot 10^{9} \mathrm{~Pa} \cdot 5.7 \cdot 10^{-6}{ }^{\circ} \mathrm{C}^{-1} \cdot 100^{\circ} \mathrm{C}=2.28 \mathrm{MPa}
$$

Thus, whereas the dense material would probably suffer a thermal shock rupture, the porous one present better chances of maintain it integrity.

Figure 24: Dilatometric analysis of sintered samples $\left(1600^{\circ} \mathrm{C}\right)$ a) Thermal Linear Variation b) Linear Expansion Coefficient
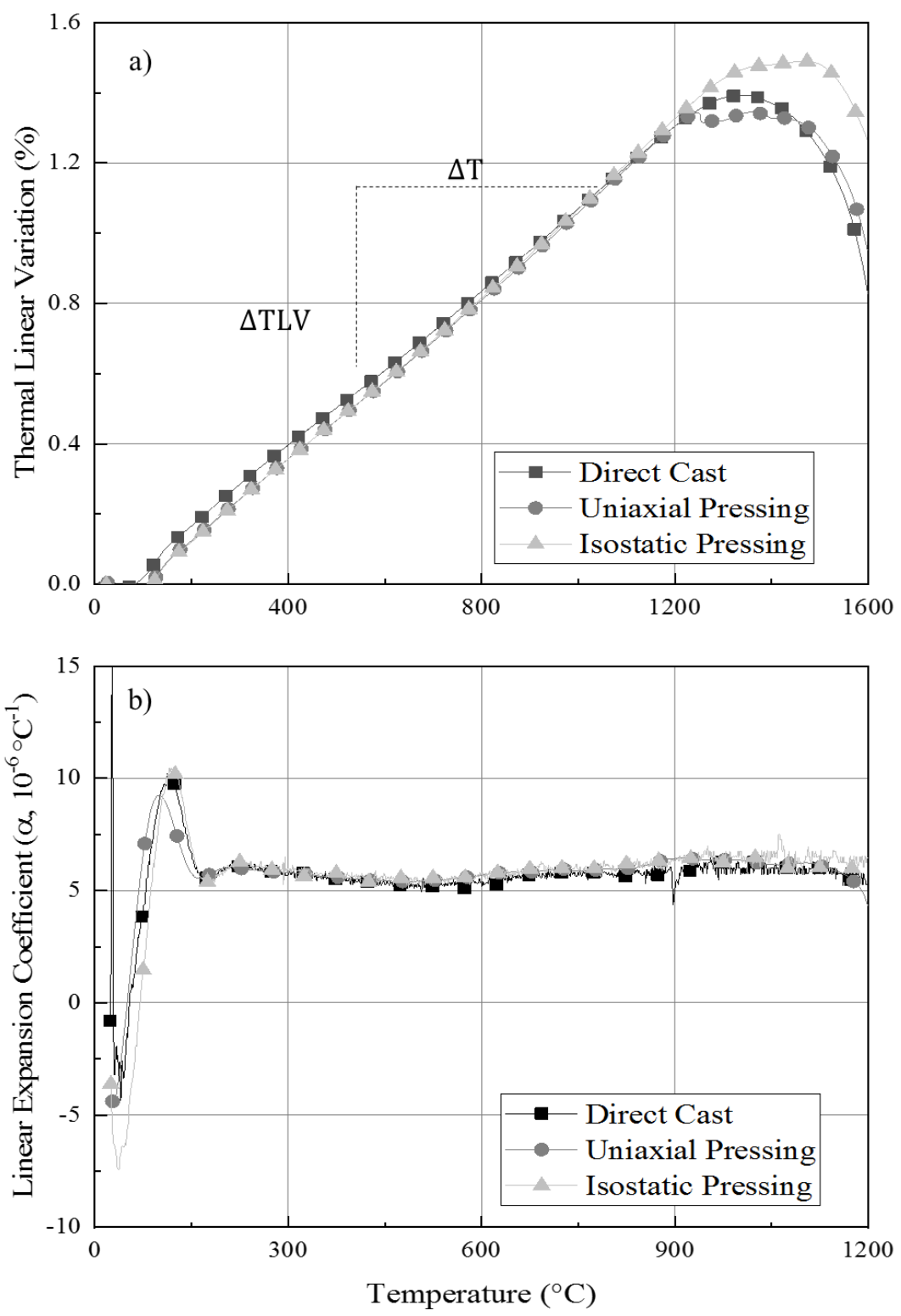

Source: Author 
Thermal conductivity was measured for the direct cast sample because it was the one that presented higher porosity levels even at $1600^{\circ} \mathrm{C}$ and mechanical properties suitable for insulator application. The values obtained were compared with materials that present low thermal conductivity and porosity levels similar to the material of this work (71.9\%) (Figure 25).

Figure 25: Thermal Conductivity of direct cast sample of this work compared to other insulators materials

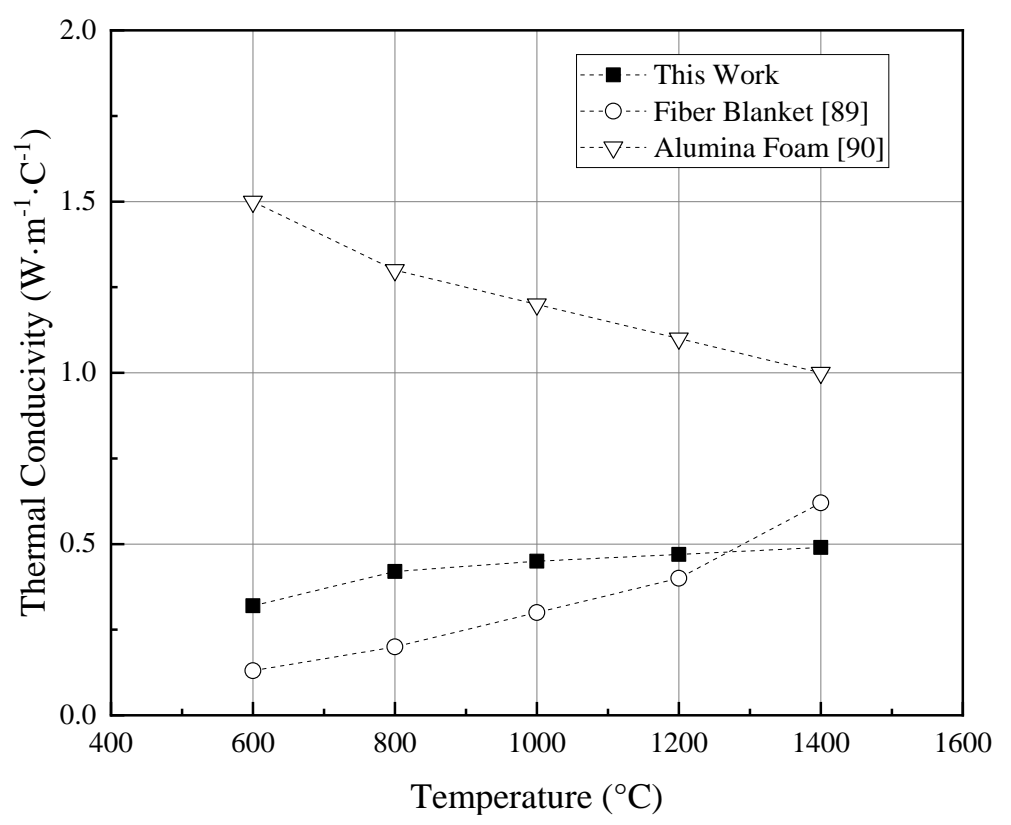

Source: Author

Fiber blanket [89] presents higher porosity $(90 \%)$ and showed lower thermal conductivity up to $1200^{\circ} \mathrm{C}$ when it becomes similar to the direct cast sample of this work and reaches higher values at $1400^{\circ} \mathrm{C}$ because at such high temperatures the main mechanism of conductivity is radiation. The material presented very low conductivity compared to alumina foam [90] with similar porosity $(72.1 \%)$ because the porous size of foam $(5 \sim 10 \mu \mathrm{m})$ is greater than coral-like $(0.7 \sim 1.2 \mu \mathrm{m})$. 


\section{CONCLUSIONS}

A new porogenesis mechanism based on surface diffusion sintering phenomena was developed to produce thermal insulators for high temperatures. It is based on the controlled compacting of previously sintered particles of aluminum hydroxide. Due to their inner porosity, such particles presented high densification-resistance. Differently for structures obtained by volume or grain boundary diffusion, this mechanism allows maintain materials' porosity and stability at high temperatures because did not promote densification since the material transport has as origin and destiny the particles' surface.

Although literature shows the possibility to use $\mathrm{Al}(\mathrm{OH})_{3}$ as a porogenic agent for dense alumina matrixes, in present work, it was verified that pure $\mathrm{Al}(\mathrm{OH})_{3}$ can not be used as the single raw materials in the production of porous ceramics. It was observed that the water withdrawal during dehydroxylation at the first heating generated cracks, and volume shrinkage, caused by phase changes generated laminations.

The previous sintering of $\mathrm{Al}(\mathrm{OH})_{3}$ up to the total conversion to $\alpha-\mathrm{Al}_{2} \mathrm{O}_{3}$ produced particles known as coral-like of high stability and intra particle porosity and presented good results as raw-material for porous ceramics. It contains a co-continuous porous phase comprised of elongated and rounded pores surrounding dense filaments of dense sintered alumina. Its stability is due to its low specific surface area and round pores with concave internal surfaces.

Three methods of processing were tested: uniaxial and isostatic pressing and direct cast. The samples directly cast were prepared with colloidal alumina and hydratable alumina because CA improved the refractory's bonding and densification at lower temperatures; those ones prepared with just HA had low green mechanical strength.

The processing routes presented different results for TP due to the compaction effects. When submitted to pressing, the filaments broke and transformed into small rounded particles, capable of compact and densify resulting in lower levels of TP $(61.5 \%$ for uniaxial and $56.3 \%$ for isostatic pressing). On the other hand, direct cast did not apply compaction force, maintaining inter-particle pores, resulting in greater TP $(74.4 \%)$.

The flexural strength (3.75 MPa) and rigidity (4.57 GPa) levels observed for DC structures were promoted by neck growth that occurred due to surface diffusion and the high dimensional stability (low shrinkage), especially at the first stage of thermal treatment, was due to the hindered densification mechanism. After sintering, these structures presented low thermal conductivity $\left(0.49\right.$ at $\left.1400^{\circ} \mathrm{C}\right)$, because of the small pore size and high porosity, and are potentially resistant to thermal shock resistance, due to the low linear expansion coefficient (5.7 
$10^{-6} \cdot{ }^{\circ} \mathrm{C}^{-1}$ at $\left.1200^{\circ} \mathrm{C}\right)$.

Particles containing highly stable internal pores were compacted in three methods: uniaxial and isostatic pressing and direct cast. The direct cast one allowed to obtain high TP and dimensional stability based on the difficult of matter transport amongst particles. Also, the processing route resulted in low thermal conductivity, consequently, these materials show potential for use as thermal insulators. 


\section{REFERENCES}

[1] INTERNATIONAL ENERGY AGENCY. Key world energy statistics. Disponível em: $<$ https://www.iea.org/statistics/kwes/consumption/>. Acesso em: 19 Sept. 2019.

[2] U. S. ENERGY INFORMATION ADMINISTRATION. Use of energy explained: energy use in industry. Disponível em: <https://www.eia.gov/energyexplained/use-of-energy/industry.php>. Acesso em: 19 Sept. 2019.

[3] PETROV, V. A. Combined radiation and conduction heat transfer in high temperature fiber thermal insulation. International Journal of Heat and Mass Transfer, v. 40, n. 9, p. 2241-2247, June 1997. DOI: 10.1016/S0017-9310(96)00242-6

[4] TYCHANICZ-KWIECIEŃ, M.; WILK, J.; GIL, P. Review of high-temperature thermal insulation materials. Journal of Thermophysics and Heat Transfer, v. 33, n. 1, p. 271-284, Jan. 2019. DOI: $10.2514 / 1 . T 5420$

[5] LE, V. T. et al. Insulation system using high-temperature fibrous insulation materials. Heat Transfer Engineering, v. 40, n. 17-18, p. 1523-1538, Nov. 2019. DOI: $10.1080 / 01457632.2018 .1474602$

[6] PARK, S.-H. Types and health hazards of fibrous materials used as asbestos substitutes. Safety and Health at Work, v. 9, n. 3, p. 360-364, Sept. 2018. DOI: 10.1016/j.shaw.2018.05.001

[7] VIVALDINI, D. O. et al. Revisão: fundamentos e materiais para o projeto da microestrutura de isolantes térmicos refratários de alto desempenho. Cerâmica, v. 60, n. 354, p. 297-309, June 2014. DOI: $10.1590 /$ S0366-69132014000200021

[8] ROMANO, R. C. O.; PANDOLFELLI, V. C. Production and properties of porous ceramics obtained by foam addition technique. Cerâmica, v. 52, n. 322, p. 213-219, 2006.

[9] GE, S. et al. Synthesis of hierarchically porous mullite ceramics with improved thermal insulation via foam-gelcasting combined with pore former addition. Advances in Applied Ceramics, v. 117 , n. 8 , p. $493-499$, Nov. 2018. DOI: $10.1080 / 17436753.2018 .1502065$

[10] ORTEGA, F. S. et al. Alternative gelling agents for the gelcasting of ceramic foams. Journal of the European Ceramic Society, v. 23, n. 1, p. 75-80, Jan. 2003. DOI: 10.1016/S09552219(02)00075-4

[11] GARRN, I. et al. Clot-forming: the use of proteins as binders for producing ceramic foams. Journal of the European Ceramic Society, v. 24, n. 3, p. 579-587, Mar. 2004. DOI: 10.1016/S0955-2219(03)00259-0

[12] LUYTEN, J. et al. Different methods to synthesize ceramic foams. Journal of the European Ceramic Society, v. 29, n. 5, p. 829-832, Mar. 2009. DOI: 10.1016/j.jeurceramsoc.2008.07.039

[13] LYCKFELDT, O.; FERREIRA, J. M. F. Processing of porous ceramics by 'starch consolidation.' Journal of the European Ceramic Society, v. 18, n. 2, p. 131-140, Jan. 1998. DOI: 10.1016/S0955-2219(97)00101-5

[14] LOPES, R. A.; SEGADAES, A. M. Microstructure, permeability and mechanical behaviour of ceramic foams. Materials Science and Engineering: A, v. 209, n. 1-2, p. 149-155, May 1996. 
$10.1016 / 0921-5093(95) 10146-2$

[15] DENG, Z. Y. et al. High-surface-area alumina ceramics fabricated by the decomposition of $\mathrm{Al}(\mathrm{OH})_{3}$. Journal of the American Ceramic Society, v. 84, n. 3, p. 485-491, 2001.DOI: 10.1111/j.1151-2916.2001.tb00687.x

[16] STUDART, A. R. et al. Processing routes to macroporous ceramics: a review. Journal of the American Ceramic Society, v. 89, n. 6, p. 1771-1789, Jun. 2006. DOI: 10.1111/j.15512916.2006.01044.x

[17] SOUZA, A. D. V. et al. Characterization of aluminum hydroxide $\left(\mathrm{Al}(\mathrm{OH})_{3}\right)$ for use as a porogenic agent in castable ceramics. Journal of the European Ceramic Society, v. 35, n. 2, 2015. DOI: 10.1016/j.jeurceramsoc.2014.09.010.

[18] SOUSA, L. L.; SALOMÃO, R.; ARANTES, V. L. Development and characterization of porous moldable refractory structures of the alumina-mullite-quartz system. Ceramics International, v. 43, n. 1, p. 1362-1370, 2017. DOI: 10.1016/j.ceramint.2016.10.093

[19] SALOMÃO, R. et al. Mechanism of pore generation in calcium hexaluminate $\left(\mathrm{CA}_{6}\right)$ ceramics formed in situ from calcined alumina and calcium carbonate aggregates. Journal of the European Ceramic Society, v. 36, n. 16, p. 4225-4235, Dec. 2016. DOI: 10.1016/j.jeurceramsoc.2016.05.026

[20] COSTA, L. M. M.; SAKIHAMA, J.; SALOMÃO, R. Characterization of porous calcium hexaluminate ceramics produced from calcined alumina and microspheres of Vaterite $\left(\mu-\mathrm{CaCO}_{3}\right)$. Journal of the European Ceramic Society, v. 38, n. 15, p. 5208-5218, Dec. 2018. DOI: 10.1016/j.jeurceramsoc.2018.07.034

[21] SALOMÃO, R. Nova rota de síntese de hidrotalcita $\left(\mathrm{Mg}_{6} \mathrm{Al}_{2}(\mathrm{OH})_{16}\left(\mathrm{CO}_{3}\right) \cdot \mathbf{4 H}_{2} \mathrm{O}\right)$ a partir de suspensões aquosas de $\mathrm{MgO}$ e $\mathrm{Al}(\mathrm{OH})_{3}$ e sua utilização em cerâmicas porosas para isolamento térmico em altas temperat. 2012. Tese (Livre Docência) - Escola de Engenharia de São Carlos, Universidade de São Paulo, São Carlos, 2012. DOI: 10.11606/T.18.2018.tde23072018-140228

[22] SALOMÃO, R.; BÔAS, M. O. C. V.; PANDOLFELLI, V. C. Porous alumina-spinel ceramics for high temperature applications. Ceramics International, v. 37, n. 4, p. 1393-1399, May 2011. DOI: $10.1016 /$ j.ceramint.2011.01.012

[23] SAKIHAMA, J.; SALOMÃO, R. Microstructure development in porous calcium hexaluminate and application as a high-temperature thermal insulator: a critical review. InterCeram, v. 68, n. 1, p. 66-71, 2019. DOI: 10.1007/s42411-019-0034-7

[24] OLIVEIRA, K. S. Caracterização física de cerâmicas porosas utilizadas como isolantes térmicos industriais em temperaturas entre $\mathbf{7 0 0 - 1 7 0 0}^{\circ} \mathrm{C}$. 2017. Monografia (Trabalho de Conclusão de Curso) - Escola de Engenharia de São Carlos, Universidade de São Paulo, São Carlos, 2017.DOI: 10.11606/D.18.2019.tde-06082019-105952

[25] LANDAU, L. D. et al. Diffusion and thermal conduction. In: SYKES, J. B.; PETFORD, A. D.; PETFORD, C.L. (Ed.). General physics: mechanics and molecular physics. Moscow: Elsevier, 1967. p. 318-340. DOI: 10.1016/C2009-0-10924-8

[26] SCHEFFLER, M.; COLOMBO, P. Cellular ceramics: structure, manufacturing, properties and applications. New York: John Wiley, 2005. ISBN: 978-3-527-31320-4 
[27] BI, Z. Applications-heat transfer problems. In: FINITE element analysis applications: a systematic and pratical approach. Indiana: Elsevier, 2018. p. 341-377. DOI: 10.1016/B978-0-12809952-0.00009-1

[28] ORDONEZ-MIRANDA, J.; ALVARADO-GIL, J. J. Effect of the pore shape on the thermal conductivity of porous media. Journal of Materials Science, v. 47, n. 18, p. 6733-6740, 9 Sept. 2012. DOI: $10.1007 / \mathrm{s} 10853-012-6616-7$

[29] KINGERY, W. D.; BOWEN, H. K.; UHLMANN, D. R. Introduction to ceramics. $2^{\text {nd }}$ ed. New York: John Wiley, 1976.

[30] SCHNEIDER, H.; SCHREUER, J.; HILDMANN, B. Structure and properties of mullite-a review. Journal of the European Ceramic Society, v. 28, n. 2, p. 329-344, Jan. 2008. DOI: 10.1016/j.jeurceramsoc.2007.03.017

[31] HOFMEISTER, A. M. Thermal diffusivity and thermal conductivity of single-crystal MgO and $\mathrm{Al} 2 \mathrm{O3}$ and related compounds as a function of temperature. Physics and Chemistry of Minerals, v. 41, n. 5, p. 361-371, May 2014. DOI: 10.1007/s00269-014-0655-3

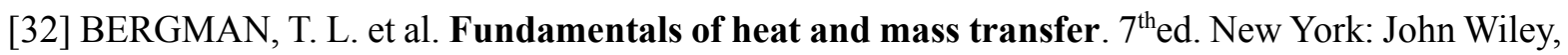
2011.

[33] WARD, A. et al. Ab initio theory of the lattice thermal conductivity in diamond. Physical Review B, v. 80 , n. 12 , p. 125203 , Sept. 2009. DOI: 10.1103/PhysRevB.80.125203

[34] BRAGINSKY, L. et al. High-temperature thermal conductivity of porous $\mathrm{Al}_{2} \mathrm{O}_{3}$. Physical Review B, v. 70, n. 13, p. 134201, Oct. 2004. DOI: 10.1103/PhysRevB.70.134201

[35] SHENG, J. J. Steam flooding. In: ENHANCED oil recovery field case studies. Texas: Elsevier, 2013. p. 361-388. DOI: 10.1016/B978-0-12-386545-8.00015-4

[36] SCHEITHAUER, U. et al. Alternative process routes to manufacture porous ceramicsopportunities and challenges. Materials, v. 12, n. 4, p. 663, Feb. 2019. DOI: $10.3390 / \mathrm{ma} 12040663$

[37] ROUQUEROL, J. et al. Recommendations for the characterization of porous solids (Technical Report). Pure and Applied Chemistry, v. 66, n. 8, p. 1739-1758, Jan. 1994. DOI: 10.1351/pac199466081739

[38] HAMMEL, E. C.; IGHODARO, O. L. R.; OKOLI, O. I. Processing and properties of advanced porous ceramics: an application based review. Ceramics International, v. 40, n. 10, p. 15351-15370, Dec. 2014. DOI: 10.1016/j.ceramint.2014.06.095

[39] OHJI, T.; FUKUSHIMA, M. Macro-porous ceramics: processing and properties. International Materials Reviews, v. 57, n. 2, p. 115-131, Mar. 2012. DOI: 10.1179/1743280411Y.0000000006

[40] SHEPHERD, J. H.; FRIEDERICHS, R. J.; BEST, S. M. Synthetic hydroxyapatite for tissue engineering applications. In: HYDROXYAPATITE (Hap) for biomedical applications. New York: Elsevier, 2015. p. 235-267. DOI: 10.1016/B978-1-78242-033-0.00011-0

[41] TATSUKI, O. Porous ceramic materials. In: SOMIYA, S. (Ed.). Handbook of advanced ceramics. $2^{\text {nd }}$ ed. New York: Elsevier, 2013. p. 1131-1143. DOI: 10.1016/C2010-0-66261-4 
[42] SCOTTI, K. L.; DUNAND, D. C. Freeze casting - a review of processing, microstructure and properties. Progress in Materials Science, v. 94, p. 243-305, May 2018. DOI: 10.1016/j.pmatsci.2018.01.001

[43] DEVILLE, S. Freeze-casting of porous ceramics: a review of current achievements and issues. Advanced Engineering Materials, v. 10, n. 3, p. 155-169, Mar. 2008. DOI: 10.1002/adem.200700270

[44] MONTANARO, L. et al. Ceramic foams by powder processing. Journal of the European Ceramic Society, v. 18, n. 9, p. 1339-1350, Jan. 1998. DOI: 10.1016/S0955-2219(98)00063-6

[45] SOUZA, A. D. V. et al. $\mathrm{Al}_{2} \mathrm{O}_{3}-\mathrm{Al}(\mathrm{OH})_{3}$-Based castable porous structures. Journal of the European Ceramic Society, v. 35, n. 6, p. 1943-1954, Jun. 2015. DOI: 10.1016/j.jeurceramsoc.2015.01.003

[46] SALOMÃO, R. et al. Effects of the initial $\mathrm{CaO}-\mathrm{Al}_{2} \mathrm{O}_{3}$ ratio on the microstructure development and mechanical properties of porous calcium hexaluminate. Ceramics International, v. 44, n. 2, p. 2626-2631, Feb. 2018. DOI: 10.1016/j.ceramint.2017.11.010

[47] SOUSA, L. L. et al. Development of densification-resistant castable porous structures from in situ mullite. Ceramics International, v. 41, n. 8, p. 9443-9454, Sept. 2015. DOI: 10.1016/j.ceramint.2015.03.328

[48] GERMAN, R. M. Coarsening in sintering: grain shape distribution, grain size distribution, and grain growth kinetics in solid-pore systems. Critical Reviews in Solid State and Materials Sciences, v. 35, n. 4, p. 263-305, Nov. 2010. DOI: 10.1080/10408436.2010.525197

[49] GERMAN, R. M.; MUNIR, Z. A. Surface area reduction during isothermal sintering. Journal of the American Ceramic Society, v. 59, n. 9-10, p. 379-383, Sept. 1976. DOI: 10.1111/j.11512916.1976.tb09500.x

[50] GERMAN, R. Thermodynamic and kinetic treatments. In: SINTERING: from empirical observations to scientific principles. Oxford: Elsevier, 2014. p. 182-226. DOI: 10.1016/C20120-00717-X

[51] GERMAN, R. M. Fundamentals of sintering. In: FANG, Z. Z. (Ed.). Sintering of advanced materials: fundamentals and process. San Diego: Woodhead, 2010. p. 1-31. DOI: $10.1533 / 9781845699949$

[52] MACKENZIE, J. K.; SHUTTLEWORTH, R. A Phenomenological Theory of Sintering. Proceedings of the Physical Society. Section B, v. 62, n. 12, p. 833-852, Dec. 1949. DOI: $10.1088 / 0370-1301 / 62 / 12 / 310$

[53] JOHNSON, D. L. Fundamentals of the sintering of ceramics. In: PROCESSING of crystalline ceramics. Boston: Springer, 1978. p. 137-149. DOI: 10.1007/978-1-4684-3378-4_13

[54] WALKER, R. F. Mechanism of material transport during sintering. Journal of the American Ceramic Society, v. 38, n. 6, p. 187-197, June 2006. DOI: 10.1111/j.1151-2916.1955.tb14928.x

[55] KINGERY, W. D.; FRANCOIS, B. The Sintering of crystalline oxides, I. Interactions between grain boundaries and pores. In: SÕMIYA, S.; MORIYOSHI, Y. (Ed.). Sintering key papers. 
New York: Springer, 1967. p. 449-466. DOI: 10.1007/978-94-009-0741-6_29

[56] BURKE, J. Recrystallization and sintering in ceramics. In: SOMIYA, S.; MORIYOSHI, Y. (Ed.). Sintering key papers. Massachusetts: Elsevier Applied Science, 1990. p. 17-38. DOI: 10.1007/978-94-009-0741-6_2

[57] GALAKHOV, A. V. Pore coordination number and sintering. Refractories and Industrial Ceramics, v. 51, n. 2, p. 83-87, 2010. DOI: 10.1007/s11148-010-9264-y

[58] GERMAN, R. M. Coordination number changes during powder densification. Powder Technology, v. 253, p. 368-376, Feb. 2014. DOI: 10.1016/j.powtec.2013.12.006

[59] KELLETT, B. J.; LANGE, F. F. Thermodynamics of densification: i, sintering of simple particle arrays, equilibrium configurations, pore stability, and shrinkage. Journal of the American Ceramic Society, v. 72, n. 5, p. 725-734, May 1989. DOI: 10.1111/j.1151-2916.1989.tb06208.x

[60] LANGE, F. F. Sinterability of agglomerated powders. Journal of the American Ceramic Society, v. 67 , n. 2, p. 83-89, Feb. 1984. DOI: 10.1111/j.1151-2916.1984.tb09620.x

[61] VARELA, J. A.; WHITTEMORE, O. J.; LONGO, E. Pore size evolution during sintering of ceramic oxides. Ceramics International, v. 16, n. 3, p. 177-189, Jan. 1990. DOI: 10.1016/02728842(90)90053-I

[62] WHITTEMORE, O. J.; SIPE, J. J. Pore growth during the initial stages of sintering ceramics. Powder Technology, v. 9, n. 4, p. 159-164, Apr. 1974. DOI: 10.1016/0032-5910(74)80027-6

[63] WEFERS, K.; MISRA, C. Oxides and hydroxides of aluminum. Pittisburg: Alcoa Laboratories, 1987.

[64] KOGURE, T. Dehydration sequence of gibbsite by electron-beam irradiation in a TEM. Journal of the American Ceramic Society, v. 82, n. 3, p. 716-720, Dec. 2004. DOI: 10.1111/j.11512916.1999.tb01822.x

[65] GAN, B. K.; MADSEN, I. C.; HOCKRIDGE, J. G. In situ X-ray diffraction of the transformation of gibbsite to $\alpha$-alumina through calcination: effect of particle size and heating rate. Journal of Applied Crystallography, v. 42, n. 4, p. 697-705, Aug. 2009. DOI: $10.1107 / \mathrm{S} 0021889809021232$

[66] ZHOU, R.-S.; SNYDER, R. L. Structures and transformation mechanisms of the $\eta, \gamma$ and $\theta$ transition aluminas. Acta Crystallographica Section B Structural Science, v. 47, n. 5, p. 617630, Oct. 1991. DOI: 10.1107/S0108768191002719

[67] SOUZA, A. D. V.; SALOMÃO, R. Evaluation of the porogenic behavior of aluminum hydroxide particles of different size distributions in castable high-alumina structures. Journal of the European Ceramic Society, v. 36, n. 3, p. 885-897, Feb. 2016. DOI: 10.1016/j.jeurceramsoc.2015.11.019

[68] DENG, Z.-Y. et al. Microstructure and Mechanical Properties of Porous Alumina Ceramics Fabricated by the Decomposition of Aluminum Hydroxide. Journal of the American Ceramic Society, v. 84, n. 11, p. 2638-2644, Nov. 2001. DOI: 10.1111/j.1151-2916.2001.tb01065.x

[69] SALOMÃO, R.; FERNANDES, L. Porous co-continuous mullite structures obtained from sintered aluminum hydroxide and synthetic amorphous silica. Journal of the European Ceramic 
Society, v. 37, n. 8, p. 2849-2856, July 2017. DOI: 10.1016/j.jeurceramsoc.2017.03.017

[70] AMERICAN SOCIETY FOR TESTING MATERIAL. ASTM C1069-09: Standard test method for specific surface area of alumina or quartz by nitrogen adsorption. Philadelphia: ASTM International, 2014.

[71] CARDOSO, F. A. et al. Drying behavior of hydratable alumina-bonded refractory castables. Journal of the European Ceramic Society, v. 24, n. 5, p. 797-802, May 2004. DOI: 10.1016/S0955-2219(03)00326-1

[72] AMERICAN SOCIETY FOR TESTING MATERIAL. ASTM, E.-01: Standard test method for dynamic young's modulus, shear modulus, and poisson's ratio by impulse excitation of vibration. Philadelphia: ASTM, 2015. Annual Book of ASTM Standards.

[73] INTERNATIONAL ORGANIZATON FOR STANDADIZATION. ISO 6872:2015: Dentistry ceramic materials. Genebra: ISO, 2015. p. 28.

[74] MIŚTA, W.; WRZYSZCZ, J. Rehydration of transition aluminas obtained by flash calcination of gibbsite. Thermochimica Acta, v. 331, n. 1, p. 67-72, June 1999. DOI: 10.1016/S00406031(99)00052-0

[75] MA, W.; BROWN, P. W. Mechanisms of reaction of hydratable aluminas. Journal of the American Ceramic Society, v. 82, n. 2, p. 453-456, Dec. 2004. DOI: 10.1111/j.15512916.1999.tb20085.x

[76] SALOMÃO, R. et al. Hydratable alumina-bonded suspensions: evolution of microstructure and physical properties during first heating. Interceram - International Ceramic Review, v. 66, n. 7, p. 28-37, Mar. 2017. DOI: 10.1007/BF03401226

[77] NOURI-KHEZRABAD, M. et al. Nano-bonded refractory castables. Ceramics International, v. 39, n. 4, p. 3479-3497, May 2013. DOI: 10.1016/j.ceramint.2012.11.028

[78] FROST, R. L.; VASSALLO, A. M. The Dehydroxylation of the kaolinite clay minerals using infrared emission spectroscopy. Clays and Clay Minerals, v. 44, n. 5, p. 635-651, 1996. DOI: 10.1346/CCMN.1996.0440506

[79] REDAOUI, D. et al. Mechanism and kinetic parameters of the thermal decomposition of gibbsite $\mathrm{Al}(\mathrm{OH})_{3}$ by thermogravimetric analysis. Acta Physica Polonica A, v. 131, n. 3, p. 562-565, Mar. 2017. DOI: 10.12693/APhysPolA.131.562

[80] GAN, B. K.; MADSEN, I. C.; HOCKRIDGE, J. G. In Situ X-ray diffraction of the transformation of gibbsite to $\alpha$-alumina through calcination: effect of particle size and heating rate. Journal of Applied Crystallography, v. 42, n. 4, p. 697-705, Aug. 2009. DOI: 10.12693/APhysPolA.131.562

[81] TSANTILIS, S.; PRATSINIS, S. E. Soft- and hard-agglomerate aerosols made at high temperatures. Langmuir, v. 20, n. 14, p. 5933-5939, July 2004. DOI: $10.1021 / 1 a 036389 \mathrm{w}$

[82] VEN, T. G. M. VAN DE; HUNTER, R. J. The Energy dissipation in sheared coagulated sols. Rheologica Acta, v. 16, n. 5, p. 534-543, Sept. 1977. DOI: 10.1007/BF01525653

[83] BRAULIO, M. A. L. et al. Colloidal alumina as a novel castable bonding system. Refractories Worldforum, v. 3, n. 3, p. 136-141, 2011. 
[84] OUYANG, Y. et al. A New strategy for dense $\mathrm{Al}_{2} \mathrm{O}_{3}$ ceramics by spherical powders prepared via thermal plasma. Ceramics International, 2019. DOI: 10.1016/j.ceramint.2018.10.099

[85] SCIAMANNA, V.; NAIT-ALI, B.; GONON, M. Mechanical properties and thermal conductivity of porous alumina ceramics obtained from particle stabilized foams. Ceramics International, 2015. DOI: $10.1016 /$ j.ceramint.2014.10.011

[86] TALLON, C. et al. Mechanical strength and damage tolerance of highly porous alumina ceramics produced from sintered particle stabilized foams. Ceramics International, v. 42, n.7, 2016. DOI: 10.1016/j.ceramint.2016.02.069.

[87] SCHAFFÖNER, S. et al. Refractories containing fused and sintered alumina aggregates: Investigations on processing, particle size distribution and particle morphology. Ceramics International, $\quad 2017 . \quad$ DOI: $\quad$ 10.1016/j.ceramint.2016.12.067.DOI: 10.1016/j.ceramint.2016.12.067

[88] SHACKELFORD, J. F.; ALEXANDER, W. (Ed.). Thermal Properties of materials. In: MATERIALS science and engineering handbook. $3^{\text {th }}$ ed. New York: CRC Press, 2001. p. 396-552.

[89] SCHNABEL, M. et al. Advantages of calcium hexaluminate in a corrosive environment. Refractories Worldforum, v. 3, n. 4, p. 87-94, 2011.

[90] SEPULVEDA, P. et al. Thermal conductivity of gelcast porous alumina. American Ceramic Society Bulletin, v. 78, n. 2, p. 61-66, 1999. 


\section{PUBLICATIONS IN THE PERIOD}

R. Salomão, M.A. Kawamura, A.B.V. Emilio, A.M. Segadães, "Calcium aluminate cement in castable alumina: From hydrate bonding to the in situ formation of calcium hexaluminate", accepted for publication in Ceramics International (2021). 